University of Konstanz

Department of Economics

Does Government I deology I nfluence Budget Composition?

Empirical Evidence from OECD Countries

\author{
Niklas Potrafke
}

Working Paper Series 2010-16 


\title{
Does government ideology influence budget composition? Empirical evidence from OECD countries
}

\author{
Niklas Potrafke ${ }^{1}$ \\ University of Konstanz
}

This version: December 13, 2010

\begin{abstract}
This paper examines whether government ideology has influenced the allocation of public expenditures in OECD countries. I analyze two datasets that report different expenditure categories and cover the time periods 1970-1997 and 1990-2006, respectively. The results suggest that government ideology has had a rather weak influence on the composition of governments' budgets. Leftist governments, however, increased spending on "Public Services" in the period 1970-1997 and on "Education" in the period 1990-2006. These findings imply, first, that government ideology hardly influenced budgetary affairs in the last decades, and thus, if ideology plays a role at all, it influences non-budgetary affairs. Second, education has become an important expenditure category for leftist parties to signal their political visions to voters belonging to all societal groups.
\end{abstract}

Keywords: budget composition, public expenditures, government ideology, partisan politics, education policy, panel data

JEL Classification: D72, H50, H61, I28, C23

\footnotetext{
${ }^{1}$ University of Konstanz, Department of Economics, Box 138, D-78457 Konstanz, Germany, Phone: +497531 88 2137, Fax: + 49753188 3130. Email: niklas.potrafke@,uni-konstanz.de
} 


\section{Introduction}

Investigating the determinants of public spending is one of the prominent topics of Public Economics. While previous research has focused on the size of government, many scholars have recently also investigated the composition of public expenditures. Political institutions have been shown to be important determinants of budget composition. LagoPeñas and Lago-Peñas (2009), for example, show that party linkage or the nationalization of party systems (as measured by the effective number of parties at the national level in relation to the effective number at the district level) has influenced budget composition in 18 Western European countries in the period 1970-1998. The reason is that in weakly nationalized party systems, sub national parties are important veto players that impede changes in the national budget composition. In Argentina, presidents have distributed capital expenditures (the more flexible item of the National Budget) to their home provinces and provinces administered by governors affiliated with their party (Bercoff and Meloni 2009). By contrast, globalization has hardly influenced budget composition (Dreher et al. 2008a, 2008b, Sanz and Velázquez 2007, Gemmell et al. 2008, Shelton 2007). The influence of government ideology on the composition of public spending, on the other hand, has been completely ignored in cross national studies. Scholars have investigated how government ideology has influenced the composition of public expenditures at the state level in federal states such as Canada (e.g., Kneebone and McKenzie 2001) or Germany (e.g., Potrafke 2011a). Given the importance of ideology-induced preferences in designing government budgets, this is a surprising omission. Another reason for manipulating the budget are electoral considerations. In this paper, however, I will focus on the influence of government ideology and do not investigate electoral cycles (see, e.g., Vergne 2009 , Katsimi and Sarantides 2010).

Budgets are often considered to represent government programs in numbers. The revenues and the need to service predetermined budget positions notwithstanding, each government can choose its spending priorities. Governments are not able to change budgets 
completely, of course. Path dependence and long-run spending commitments influence public expenditures (see, for example, Rose's 1990 "inheritance before choice" in public policy). The composition of the budget will however reflect the preferences of the government and its constituencies. Leftwing and rightwing governments are expected to place emphasis on different budget positions with a view to gratifying their clientele. ${ }^{2}$

Many scholars have investigated how government ideology influences the size of government as measured by the government budget in OECD panels, but they have not examined the composition of the budget. To be sure, I acknowledge that Bräuninger (2005) introduces a partisan model of government expenditures and provides empirical evidence for the period 1971-1999, distinguishing only two expenditure categories. His results suggest that the actual spending preferences of parties matter, but these preferences do not appear to be governed by a clear-cut left-right alignment. Evaluating whether leftwing and rightwing governments set other budget priorities requires analyzing many expenditure categories that mirror various policy fields. The more comprehensive the classifications of government expenditure, the higher the probability that policy effects remain undetected.

In this paper, I employ the COFOG (Classification of the Functions of Government) classifications of government functions. I analyze the dataset by Sanz and Velázquez (2007) that covers the period 1970-1997, and a more recent OECD dataset covering the period 19902006 in order to examine whether government ideology had an influence on the allocation of public expenditures. The results suggest that government ideology has had a rather weak influence on the composition of government budgets. Leftist governments, however, increased spending on "Public Services" in the period 1970-1997 and on "Education" in the period 1990-2006. These findings imply, first, that government ideology hardly influenced budgetary affairs in the last decades, and thus, if ideology plays a role at all, it influences non-

\footnotetext{
${ }^{2}$ On the influence of party alternation of fiscal performance see, for example, Calcagno and Escaleras (2007).
} 
budgetary affairs. Second, education has become an important expenditure category for leftist parties to signal their political visions to voters belonging to all societal groups.

The paper is organized as follows: Section 2 discusses theoretical and empirical studies on the partisan approach and budget composition. Section 3 presents the data. Section 4 specifies the empirical model. Section 5 reports and discusses the estimation results, and investigates their robustness. Section 6 concludes.

\section{Government ideology and budget composition}

Politicians' behavior is expected to affect economic policy. The political business cycle and partisan theories indicate how politicians will influence economic outcomes. ${ }^{3}$ The partisan approach focuses on the role of party ideology and shows to what extent leftwing and rightwing politicians can pursue different policies that reflect the preferences of their partisan constituencies. Leftist parties appeal more to the labor base and promote expansionary fiscal and monetary policies, whereas rightwing parties appeal more to capital owners, and are therefore more concerned with reducing inflation. This holds for both branches of the partisan theory - for the classical approach (Hibbs 1977) and for the rational approach (Alesina 1987). For empirical evaluations of the partisan theories see, e.g., Alesina et al. (1997), Sakamoto (2008), Heckelman (2002), Tavares (2004), Bjørnskov (2008a), Potrafke (2011b). ${ }^{4}$

In addition to determining the size of the budget, parties also determine the allocation of specific government spending with a view to gratifying their clientele (Bräuninger 2005, Drazen and Eslava 2010). A key difference between leftwing and rightwing parties concerns their different views on taxation, public good provision and income redistribution. Individuals

\footnotetext{
${ }^{3}$ One implication of the political business cycle theories (Nordhaus 1975 and Rogoff and Sibert 1988, among others) is that all politicians will implement the same expansionary economic policy before elections. For theoretical enhancements and empirical evaluations see, for example, Shi and Svensson (2006) or Angelopoulos and Economides (2008).

${ }^{4}$ Yet there is no conclusive empirical evidence that leftist governments in fact promote more expansionary policies. The results by Alt and Lassen (2006), for example, suggest that right-wing governments tend to have higher deficits than left-wing governments.
} 
with a high income and high skills, which are associated with rightwing parties, are expected to lobby for public expenditures spent on public good provision, just in order to prevent public money from being spent on transfers. In a similar vein, individuals with a low income and low skills, which are associated with leftwing parties, are expected to lobby against public expenditures on public good provision, because it implies a reduction of direct income transfers (Bierbrauer 2009).

Social policy has traditionally been politically controversial. Hicks and Swank (1992), for example, provide theory and evidence to describe how policy influences welfare spending in industrialized countries. Following the social democratic corporatist perspective, leftwing and centrist government parties generate higher welfare efforts than rightwing and "intermediate" parties. Scholars have extensively investigated how government ideology has influenced social policy and many have focused on overall social expenditures. Empirical evidence detects higher social expenditures under leftist than rightwing governments till the end of the "cold war" in 1990, whereas partisan effects disappeared in the 1990s (e.g., Kittel and Obinger 2003, Potrafke 2009a, Congleton and Bose 2010). The reason is that all parties reduced social expenditures compared to the period 1960-1980s (e.g. Huber and Stephens 2001, Pierson 1996 and 2001). Over the period 1980-2005, leftwing governments somewhat delayed social expenditure cutbacks in OECD countries (Tepe and Vanhuysse 2010). In traditionally leftwing countries such as the Scandinavian countries, rightwing governments have however been shown to spend more on social welfare than leftwing governments. This is because rightwing governments are forced to compensate for the lack of public trust by being even more generous than leftwing governments (Jensen 2010). All that notwithstanding, I hypothesize that leftwing government favor higher total social spending.

In a similar vein, leftist governments are expected to increase the role of government in health policy and therefore increase public health expenditures. Immergut (1992: 1) describes how politicians implement different health policies and comes to the following 
conclusion: "National health insurance symbolizes the great divide between liberalism and socialism, between the free market and the planned economy...Political parties look to national health insurance programs as a vivid expression of their distinctive ideological profiles and as an effective means of getting votes National health insurance, in sum, is a highly politicized issue.” De Donder and Hindricks (2007) examine the political economy of social insurance policy and demonstrate that in a two party model, the leftwing party proposes more social insurance than the rightwing party. The rightwing party attracts the richer individuals, and those with smaller health risks, and the leftwing party attracts the poorer individuals, and those with higher health risks.

By contrast, Jensen (2011a) argues that in modern welfare states, both leftwing and rightwing parties expand public health spending. While previous studies have established theories how leftwing governments extend the public health system and considered rightwing governments only as counterparts to leftwing governments, Jensen (2011a) explicitly develops a theory how rightwing governments implement health policies. Rightwing governments face the following dilemma: they need to consider the pro-public preferences of the important middle-class voters and the preferences of the pro-private preferences of the high-income voters. Moreover, in almost all industrialized countries except the United States, compulsory public health systems have been established. A majority of the voters appears to be strictly against severe cuts in the public health system. ${ }^{5}$ Rightwing governments are expected to solve this dilemma by a strategy called "marketization via compensation". This strategy consists of two components. First, rightwing governments match health policies of the political left and keep public health spending at a quite high level. Second, rightwing governments actively encourage and financially support private market health care such as

\footnotetext{
${ }^{5}$ After overall public spending had increased in the course of the recession in the beginnings of the 1980s, the rightwing governments lead by Margret Thatcher and Ronald Reagan eventually curbed social transfers and cut public spending on capital formation and industrial subsidies. Spending on social affairs, however, was not reduced. (Boix 1998: 192) explains this strategy as follows: "Strict electoral calculations partially explain the Conservatives' conscious rejection of any substantial reduction in core welfare programs to achieve their overall goal of lower public expenditure. Popular support for the welfare state was just too strong."
} 
indirect support of private health insurance. The empirical results by Jensen (2011a, 2011b) and Potrafke (2010a) show that government ideology has not influenced public health expenditures in OECD countries. In a similar vein, the results by Tepe and Vanhuysse (2009b: footnote 5) suggest that government ideology did not influence pension expenditures in OECD countries.

Political ideology also influences environmental policy. Leftwing parties and, in particular, leftist Green parties, have put emphasis on environmental protection. The model by Cremer et al. (2008), for example, predicts that leftwing parties (Democrats) propose higher emission tax rates than rightwing parties (Republicans) if intra-party polarization is high and the militant party faction dominates the overall party profile. If the opportunistic (electionmotivated) party faction dominates the overall party profile, both the leftwing and the rightwing party offer the same emission tax rate (Cremer et al. 2008 do not test this claim empirically). Conventional wisdom is that leftwing parties are more active in environmental protection. Christian Democratic parties are, however, concerned, about the integrity of the divine creation and are thus also concerned about environmental quality. ${ }^{6}$ Policy platforms of traditional parties (Social Democrats and Christian Democrats) and Green Parties have converged in the last decades. Laurency and Schindler (2010) show that international climate agreements that reduce greenhouse gas emissions and decrease effective abatement costs have induced convergence in policy platforms: the higher is the flexibility and cost reduction in international agreements, the more Green parties lose their unique green policy position because non-Green parties will be more flexible in adjusting their party platforms.

The relationship between government ideology and public spending on economic affairs appears to be ambiguous. Leftwing and rightwing governments have different preferences on the size and scope of government and thus on economic policy. Leftwing governments are in favor of strongly regulating the economy. In contrast, rightwing

\footnotetext{
${ }^{6}$ Ono (2009) discusses intergenerational conflicts about the composition of public spending over environmental investment and social security.
} 
governments believe in the free market and thus favor less state intervention. ${ }^{7}$ For this reason, spending on economic affairs should be lower under rightwing than under leftwing governments. Spending on economic affairs includes, however, spending on fuel and energy industries as well as agriculture. These industries appear to be more associated with rightwing than leftwing parties. ${ }^{8}$

Leftist governments are expected to spend more on education than conservative governments. The significant difference between leftwing and rightwing governments in the education system is that leftwing governments favor the expansion of public authority in the education system, whereas rightwing governments favor private alternatives (Busemeyer 2009a). In Switzerland, for example, social democratic ideology has had a negative influence on privatizing education (Merzyn and Ursprung 2005). Scholars have recently investigated the influence of government ideology on total education spending and mostly find that overall education spending was higher under leftwing governments in OECD countries (Boix 1997, Schmidt 2007, Busemeyer 2007 and 2009a, and Ansell 2008). By contrast, the results by Jensen (2011c) do not suggest that overall education spending was higher under leftwing governments in the period 1980-2000 in OECD countries. Jensen's (2011c) argument confronts with the so called "Boix model" predicting that total education spending is higher under social democratic governments: leftwing governments will not increase total education expenditure but rather decrease it because redistribution - the leftist ultimate goal - can be optimized via other policy areas such as social policy.

\footnotetext{
${ }^{7}$ For example, rightwing governments have promoted privatization in Central and Eastern Europe after the fall of the Iron Curtain (Bjørnskov and Potrafke 2011a) and have been more active in product market deregulation in OECD countries (Potrafke 2010b) and in labor market deregulation across the Canadian provinces (Bjørnskov and Potrafke 2011b).

${ }^{8}$ Social democratic parties and trade unions are assumed to have common ideological goals. In particular, the combination of leftwing governments and centralized bargaining has been shown to generate lower inflation and higher economic growth compared to decentralized bargaining under conservative governments (Lange and Garrett 1985). The model by Johansen et al. (2007) predicts, however, that in wage negotiations, trade unions appear to behave differently under a social democratic than under a conservative government. Empirical results for Norway show that changing from a conservative to a social democratic central government has significantly reduced manufacturing wages and made wages more responsive to unemployment.
} 
Education spending can be distinguished in spending on lower and higher education. An extension of the Boix model therefore predicts that leftwing governments increase spending on primary and secondary education and decrease spending on tertiary education. The reason is that the traditional clientele of leftwing parties such as workers profit more from spending on primary and secondary education than on tertiary education. In the German Laender, for example, leftwing governments have somewhat increased spending for schooling, whereas rightwing governments have increased spending for universities (Potrafke 2011a, Oberndorfer and Steiner 2007). ${ }^{9}$ The model by Ansell (2008) also shows that rightwing parties are often proponents of increased spending on universities. ${ }^{10}$ In the course of declining electoral cohesion, however, leftwing parties may want to cater for middle-class voter groups without alienating their core constituiencies. Busemeyer (2009a) therefore calls the extended Boix model into question and predicts higher spending for tertiary education under leftwing governments: "the reason why social democrats prefer public higher education institutions is that in this case the decision on the expansion of access to higher education is not delegated to private institutions, but remains within the reach of public authority" (Busemeyer 2009a: 111f.). His empirical evidence for OECD countries supports this claim. In any event, I will not distinguish between lower and higher education in this paper. At an aggregated level, I expect spending on education to be higher under leftist governments.

Rightwing governments, on the other hand, are expected to increase military expenditures (e.g. Nincic and Cusack 1979). Correa and Kim (1992) provide a survey of the literature on defense expenditure in the United States and the USSR and conclude, based on the literature as well as their own empirical research, that defense expenditures in the United States are driven by political variables. Their results, however, suggest even higher defense

\footnotetext{
${ }^{9}$ The results by Tepe and Vanhuysse (2009a) show that incumbents accelerated hiring of new teachers before elections in the German Laender.

${ }^{10}$ To be sure, the elaborate model by Ansell (2008) views partisan choices on higher education "in a trilemma between the level of enrollment, the degree of subsidization, and the overall public cost of higher education" $p$. 190). On ideology-induced education policy see also Iversen and Stephens (2008).
} 
expenditures under democratic presidents but they admit that this finding contradicts the position usually attributed and "could change if a longer time period were included in the analysis" (Correa and Kim 1992: 168). Bel and Elias-Moreno (2009) investigate military spending in 157 countries in the period 1988-2006 and find that rightwing government spent more on military affairs than leftwing governments.

Public expenditures on cultural and religious affairs are also related to societal cleavages and government ideology. For example, Schulze and Rose (1998) investigate the determinants of public orchestra funding in Germany and their results suggest that conservative and liberal politicians tend to support classical orchestras more than Social Democratic and Green politicians do. By examining voting behavior in a referendum on the construction of a concert hall in Germany, Potrafke (2010c) shows that political ideology influences cultural policy. The results suggest that resistance to the concert hall was particularly strong in electoral districts in which majorities of citizens vote for the social democrats. By contrast, constituents of rightwing parties voted more in favor of the project. This voting pattern indicates that cultural policy is ideology-induced. The constituencies of conservative parties are expected to support traditional cultural values such as theatres, concerts, operas and art exhibitions more so than voters of the left such as blue-collar workers (e.g. Schulze and Ursprung 2000). Christian Democratic parties will naturally put a higher priority on financing churches than Social Democratic parties do.

\section{Data}

There is yet no single dataset that classifies public expenditures of the general government by so called COFOG (Classification of the Functions of Government) functions and types for a longer time period, e.g., from 1970 until present. Therefore, I examine two 
different datasets classifying public expenditures of the general government ${ }^{11}$ : the one composed and used by Sanz and Velázquez (2007) (and a sub sample by Gemmell et al. 2008) covering the period 1970-1997 and the dataset from the OECD for the period 1990-2006. The dataset by Sanz and Velázquez (2007) contains yearly data for 23 OECD countries: Australia, Austria, Belgium, Canada, Denmark, Finland, France, Germany ${ }^{12}$, Greece, Iceland, Ireland, Italy, Japan, Luxembourg, the Netherlands, New Zealand, Norway, Portugal, Spain, Sweden, Switzerland, the UK, and the USA (balanced panel). The second dataset contains yearly data for the total expenditure structure of 20 OECD countries from 1990-2006. This panel is unbalanced. There are yearly data available for Belgium, Canada, Denmark, Finland, Ireland, Italy, Luxembourg, Norway, and the USA for the period 1990-2006. Data for Germany are available from 1991 to 2006, for the UK from 1990 to 2005. Austria, France, Greece, the Netherlands, Portugal, Spain and Sweden can be included with data running from 1995 to 2006. There are data for Japan from 1996 to 2006 and for Iceland from 1997 to $2006 .{ }^{13}$ I will not consider any country with fewer observations, so that there is at least some time and potential policy variation.

The examined data are public expenditures classified by so called COFOG in both cases, but they differ in some respects. First, Sanz and Velázquez (2007) combined the two categories of the original classification "General public services" and "Public safety and order" into one category named "Public services". I proceed in the same way for the second dataset from 1990 to 2006 to make the results more comparable. Hence, this expenditure category refers to the provision of publicly provided goods. Second, the new OECD classification includes a category called "Environmental protection". ${ }^{14}$ This classification

\footnotetext{
${ }^{11}$ The data refer to the general government. Hence, I am unfortunately unable to distinguish between the different jurisdictions in the single countries and take the institutional background into account. In the robustness tests section I comment on results when federal states are excluded.

${ }^{12}$ For Germany there are missing data on some control variables.

${ }^{13}$ There are also data for South Korea from 1996 to 2005 . However, South Korea is a presidential system, so that the current analysis of the political variables is not applicable.

${ }^{14}$ Most of the expenditures for "Environmental protection" were classified via "Housing" due to the former categorization.
} 
differs from previous ones, and thus, the category "Environmental protection" is not included in the dataset by Sanz and Velázquez (2007). Instead, Sanz and Velázquez (2007) split "Transport and communications" from "Economic Services" because "Transport and communications" are a kind of investment. Hence overall, both datasets distinguish between nine different expenditure categories, where eight of them are named the same in both datasets. Both datasets exclude interest payments. The appendix contains a detailed description of the single expenditure categories resulting from the classification system and descriptive statistics $^{15}$ of all variables. I will use the growth rates of these different expenditure categories as dependent variables in the base-line econometric model.

\section{The empirical model}

The estimated base-line dynamic panel data model has the following form:

$\Delta \ln$ Public expenditure category $\mathrm{ijt}_{\mathrm{t}}=\alpha$ Ideology $_{\mathrm{it}}+\Sigma_{1} \beta_{1} \Delta \ln \mathrm{X}_{\mathrm{ilt}}$

$$
+\gamma \Delta \ln \text { Public expenditure category } \mathrm{ijt}_{-1}+\eta_{\mathrm{i}}+\varepsilon_{\mathrm{t}}+\mathrm{u}_{\mathrm{ijt}}
$$

with $\mathrm{j}=1, \ldots, 10 ; \mathrm{l}=1, \ldots, 7$

where the dependent variable " $\Delta \ln$ Public expenditure category $y_{\mathrm{ijt}}$ " denotes the growth rate of expenditure category $\mathrm{j}$ as a share of GDP. I distinguish between nine expenditure categories and also consider total spending (as a share of GDP) as a further equation, so that there are ten equations in total. Panel unit root tests show that the growth rates of the expenditure categories are stationary. Ideology $y_{i t}$ describes the ideological orientation of the respective government. In the next paragraph I describe this variable and its coding in detail. " $\Sigma_{1} \Delta \ln$ $\mathrm{X}_{\mathrm{ilt}}$ ” contains seven exogenous control variables. I follow the related studies to include: the

\footnotetext{
${ }^{15}$ It is important to note that Spain, Portugal and Greece became democracies in the mid seventies. This explains the somewhat smaller sample size of the ideology variables.
} 
growth rates of the total population, the share of the young population (aged 14 and below as a share of total population), the share of the elderly population (aged 65 and above as a share of total population), per capita income (in real terms), international trade as share of GDP, prices of public consumption (Tridimas 2001), and the unemployment rate. Thus, the demographic development, the general economic situation, the openness of the economy, inflation and the situation of the labor market are taken into account. " $\Delta \ln$ Public expenditure category ${ }_{\mathrm{ijt}-1}$ " describes the lagged dependent variable. Lastly, $\eta_{\mathrm{i}}$ represents a fixed country effect, $\varepsilon_{\mathrm{t}}$ is a fixed period effect and $\mathrm{u}_{\mathrm{ijt}}$ describes an error term.

An important challenge in testing for the influence of government ideology is the heterogeneity of the parties and parliamentary systems in the various nation states. The question is which governments should be labeled leftwing or rightwing - especially when there are more than two parties in government with different ideological roots. I employ the ideology index by Potrafke (2009a), which is based on the index of governments' ideological positions by Budge et al. (1993) and updated by Woldendorp et al. (1998, 2000). This index places the cabinet on a left-right scale with values between 1 and 5. It takes the value 1 if the share of governing rightwing parties in terms of seats in the cabinet and in parliament is larger than $2 / 3$, and 2 if it is between $1 / 3$ and $2 / 3$. The index is 3 if the share of centre parties is $50 \%$, or if the leftwing and rightwing parties form a coalition government that is not dominated by one side or the other. The index is symmetric and takes the values 4 and 5 if the leftwing parties dominate. Potrafke's (2009a) coding is consistent across time but does not attempt to capture differences between the party-families across countries. Years in which the government changed are labeled according to the government that was in office for the longer period, e.g., when a rightwing government followed a leftwing government in August, this year is labeled as leftwing.

I now turn to discussing my choice of the panel data estimation method. In the context of dynamic estimation, the common fixed-effect estimator is biased. The estimators taking 
into account the resulting bias can be broadly grouped into the class of instrumental estimators and the class of direct bias corrected estimators (see Behr 2003, for example, for a discussion). In accordance with large sample properties of the GMM methods, e.g., the estimator proposed by Arellano and Bond (1991) will be biased in my econometric model with $\mathrm{N}=20$ or $\mathrm{N}=23$. For this reason, bias corrected estimators are more appropriate. I apply Bruno's (2005a, 2005b) bias corrected least squares dummy variable estimator for dynamic panel data models with small N. ${ }^{16}$

\section{Results}

\subsection{Basic results}

Table 1 illustrates the regression results for the period 1970-1997 and reports the coefficients and t-statistics (in absolute terms) for every single equation. The results in Table 1 show that government ideology has hardly influenced the growth of public expenditures in the period 1970-1997. First, the results report that leftist governments did not significantly extend the overall public sector. The coefficient of the ideology variable in column 1 does not turn out to be statistically significant. This finding could be driven by compensating effects and governments could have set other budget priorities. The results in Table 1, however, do not support this claim: leftist governments only increased expenditures on "Public services" (column 2) and therefore, afforded more publicly provided goods than rightwing governments. The coefficient is statistically significant at the 5\% level. Its numerical meaning is that a corresponding increase of the ideology variable by one point - say from 3 (leftist and

\footnotetext{
${ }^{16}$ I choose the Blundell-Bond (1998) estimator as the initial estimator with which the instruments are collapsed as suggested by Roodman (2006). This procedure makes sure to avoid using invalid and too many instruments (see Roodman 2006 and 2009 for further details). Following Bloom et al. (2007) I undertake 50 repetitions of the procedure to bootstrap the estimated standard errors. Bootstrapping the standard errors is common practice applying this estimator. The reason is that Monte Carlo simulations demonstrated that the analytical variance estimator performs poorly for large coefficients of the lagged dependent variable (see Bruno $2005 \mathrm{~b}$ for further details). The results do not qualitatively change with more repetitions such as 100, 200 or 500 as well as when the Arellano-Bond (1991) estimator is chosen as initial estimator.
} 
rightwing parties in government) to 4 (leftwing government) - would increase the growth rate of public expenditures for "Public services" by about $1.1 \%$. However, I expected leftist governments to spend less for "Defense" and "Cultural affairs" and more for "Housing", as well as "Health" and "Social welfare" (traditional party cleavage). The results do not fulfill these prospects and they do not just reflect the fact that the influenced expenditures are more elastic in the short run and not subject to long run contracts such as defense.

The control variables mostly display the expected sign. For example, the negative elasticities of real per capita income corroborate that, in recessions, the government will provide compensating demand by government expenditures. The estimated coefficients imply that public expenditures (as a share of GDP) decreased, e.g., by about $0.84 \%$ (overall spending, column 1 ) or by about $1.02 \%$ (social welfare, column 10 ) when the real per capita GDP increased by $1 \%$. Overall, real per capita GDP is statistically significant across the equations. In contrast, the population variables mostly do not turn out to be statistically significant. Interestingly, the elderly share is statistically significant at the $10 \%$ level on expenditures on "Education" (Column 9). The estimated coefficient has the expected negative sign and implies that public expenditures on education (as a share of GDP) decreased by about $0.51 \%$ when the elderly share increased by $1 \%$. Trade openness does not turn out to be statistically significant across the specifications, except the equation for "Education" (column 9). The negative sign of the coefficient in column 9, however, lacks intuition. Moreover, the results suggest that overall government expenditures (column 1) increased by about $0.13 \%$ when the prices of public consumption increased by $1 \%$ and by about $0.015 \%$ when the unemployment rate increased by $1 \%$. Overall, the impacts of the control variables are similar to the results by Sanz and Velázquez (2007) and Gemmell et al. (2008), as far as variables are comparable. It is important to note that their regression equations are re-parameterized. My results obviously differ from the ones by Dreher et al. (2008a, 2008b), because first, Dreher et 
al. (2008a, 2008b) estimate their models in levels (I use growth rates), and second, their sample is smaller, with only 64 observations in the COFOG set-up.

Table 2 provides the results relating to the panel from 1990 to 2006 . The results corroborate my previous findings, that parties did not influence overall government spending (column 1) and also did not significantly influence the budget composition. Leftwing governments, however, increased spending on "Education". The coefficient of the ideology variable does not turn out to be statistically significant across all other specifications. Real per capita GDP again emerges as the most important control variable indicating negative elasticities in the interval between about 1 and even 3 with respect to expenditures on “Defense" (column 3).

\subsection{Robustness of the results}

I checked the robustness of the results in several ways. First, I will discuss alternative econometric specifications of the base-line model in growth rates using somewhat different control variables and estimation procedures. The previous regressions included trade as a share of GDP, as it is common in the related literature. Following Dreher (2006) and Dreher et al. (2008a, 2008b), globalization is a multi-faceted concept that cannot be captured by a single economic indicator such as international trade, foreign direct investments or capital account restrictions. Therefore, for a robustness check, I have replaced the explanatory variable trade-openness by the KOF index of globalization (version 2008) which has been available till 2005. The demographic change could also be considered by the share of the working population. I have therefore replaced the shares of the young and the old by population aged between 15 and 64 as share of total population. To control for contemporaneous correlation across the countries I have applied panel corrected standard errors according to Beck and Katz (1996). I have also tested for the existence of arbitrary serial correlation applying the Wooldridge test (Wooldridge 2002: 176-177) in the static panel 
data model. The test implies the existence of arbitrary serial correlation in the sample 19701997 for expenditures on "Defense", "Housing", and "Social Welfare" and in the sample 1990-2006 for "Public Services", "Defense", "Economic Affairs" and "Education". Consequently, I have applied heteroskedastic and autocorrelation consistent (HAC) NeweyWest type (Newey and West 1987, Stock and Watson 2008) standard errors and variancecovariance estimates. The inferences with respect to the influence of government ideology on the budget composition, however, are not affected (results not shown).

The reported effects could depend on idiosyncratic circumstances in the individual countries. I therefore test whether the results are sensitive to the inclusion/exclusion of particular countries. Regarding the first dataset, the influence of the ideology variable on public services somewhat declines when New Zealand and the USA are excluded. Regarding the second dataset from 1990 to 2006, excluding Norway, the UK and the USA weakens the influence of the ideology variable on education spending. When Germany is excluded, however, the impact of the ideology variables increases.

The results could also depend on the chosen government ideology indicator by Potrafke (2009a). To rule out this possibility, alternative government ideology indicators can be used, such as the one by Bjørnskov $(2005,2008 \mathrm{a})$. Hence for robustness checks, I have employed the recent government ideology indicator by Bjørnskov (2008b) which has been available till 2004. Bjornskov's (2008b) index refers to the Henisz (2000) database on political outcomes since the 19th century, and the general approach to measuring political ideology follows along the lines of Bjørnskov (2005b, 2008a). However, as compared to the index employed in Bjørnskov (2005b, 2008a), the Bjørnskov (2008b) index "takes the social democrat party in a given country as an internationally comparable anchor around which other parties are placed on a five-point scale $(-1 ;-.5 ; 0 ; .5 ; 1)$ from left to right” (Bjørnskov 2008b: 5). The ideology scores of each government party are weighed with their relative share of all government party seats in parliament in order to consider differing degrees of influence on 
government policy. This procedure addresses the ideological position of the government and the parliament. Employing this index does not change the inferences.

It is conceivable that the estimates change when government ideology is lagged. I have therefore replaced the government ideology variable in period t by its lagged values in the years $t-1, t-2, t-3$ and $t-4$. The results show that the estimated influence of government ideology on "Public Services" over the period 1970-1997 and on "Education" over the period 1990-2006 are robust: while government ideology in period t-1 still has a significant and positive influence, ideology lagged by four years turns out to have a significant and negative influence. Against the background that legislative periods usually last four years and governments frequently change, this is a reasonable finding.

In my base-line econometric model, I have regressed the growth rate of the expenditure categories on the level of government ideology. This specification reveals that incumbents change the budget composition incrementally. An alternative specification is an error correction model (ECM) that allows distinguishing between long-run and short-run effects of government ideology. I have therefore also estimated an ECM. ${ }^{17}$ The regression results reported in Tables 3 (dynamic bias corrected estimator) illustrate that government ideology hardly influenced the budget composition in the period 1970-1997. The ideology variables in column (2) still have a positive sign but fail statistical significance at conventional levels. The first difference of ideology variable in levels is statistically significant at the $10 \%$ level in column (5) indicating that leftwing government somewhat increased spending for "Transport and communications" in the short run. The results are however somewhat sensitive to the estimation procedure: the long-run ideology-induced effects on public services is statistically significant at the $1 \%$ level when panel corrected standard errors and at the 5\% level when FGLS with heteroskedastic and autocorrelation

\footnotetext{
${ }^{17}$ In an ECM, the first differences of the expenditure categories are regressed on the first differences of the explanatory variables (short-run effect) and the lagged levels of the explanatory variables (long-run effect). I have estimated ECM using Bruno's estimator, panel corrected standard errors and FGLS with heteroskedastic and autocorrelation consistent standard errors.
} 
consistent standard errors are used. The results in Table 4 show that in the long-run, expenditures for "Education" in the period 1990-2006 were higher under leftwing governments. The coefficient of the ideology variable is statistically significant at the $1 \%$ level. This result is however also somewhat sensitive to the estimation procedure because the effect does not turn out to be statistically significant when panel corrected standard errors and FGLS with heteroskedastic and autocorrelation consistent standard errors are used.

A caveat applying to all panel data models concerns potential endogeneity of the explanatory variables. In my analysis, it is, however, not reasonable to believe that government ideology is influenced by budget composition. Moreover, good instrumental variables for government ideology are not available. It is important to note in particular that instrumenting ideology with the help of lagged government ideology would not be reasonable because ideology is a highly persistent variable.

In several federal states, the federal governments are not responsible for expenditures on education such as schools and universities. Education policy is a matter of the state governments. For this reason, I have excluded the federal states Austria, Germany, Canada and the United States to check the robustness of the ideology-induced effect on education expenditures in the period 1990-2006. Inferences do not change at all (I have used several estimation techniques): leftwing governments increased education expenditures in the period 1990-2006. Government ideology did not influence education spending in the 1970-1997 sub sample, when the federal states (Austria, Germany, Canada, Switzerland and the United States) are excluded.

\section{Conclusions}

Government ideology has had a rather weak influence on the composition and the size of governments' budgets in OECD countries. Leftist governments, however, increased spending on "Public Services" in the period 1970-1997 and on "Education" in the period 
1990-2006. The lack of ideology-induced fiscal policy making confirms related empirical findings that government ideology hardly concerned budgetary affairs in the last two decades, but ideology-induced effects can be identified in non-budgetary affairs. For example, government ideology has had a strong influence on political alignment with the United States: leftwing governments were less sympathetic to US positions (Potrafke 2009b). The distinctly different alignments of leftist and rightwing governments with the United States reflect sources of ideological association that transcend issues of economic policy. Future research may therefore investigate further how government ideology influences non-budgetary affairs and also issues that do not relate the economy such as international relations or migration policy (see, e.g., Schneider and Urpelainen 2010).

Globalization could counteract partisan politics, or even restricts politicians' options or ability to maneuver. Leftist governments are, for example, believed to have lost the ability to implement their preferred policies such as direct income redistribution. The available empirical evidence for the OECD countries, however, does not indicate that globalization has counteracted partisan politics (Potrafke 2009a) and that globalization demolishes the welfare state. The results presented by Dreher et al. (2008a) suggest, for example, that globalization did not affect budget composition, whereas Busemeyer (2009b) finds a negative association between trade-openness and public spending in OECD countries (see Dreher et al. 2008b; Schulze and Ursprung 1999, and Ursprung 2008 for surveys of the literature on the nexus between globalization and the welfare state).

Why is it that in times of declining electoral cohesion education policy appears to emerge as a central policy field that attracts attention of various societal groups? Equality of opportunity has always been a concern in the political debate but has for a long time been overshadowed by equality of distribution. Since direct income redistribution is no longer feasible, equality of opportunity takes a centre stage position. As far as education policy is concerned, it is well known that the family background has an important influence on the 
return to education. Even university students with a minority background and from schools located in economically disadvantaged areas, are likely to be academically less successful (Betts and Morrell 1999). For this reason, unprivileged citizens are in favor of higher public education expenditures with the consequence that leftist parties will focus on this policy field to gratify their original constituencies and, for example, try to reduce income inequality (on distributional effects of public education expenditures see, for example, Sylwester 2002 and Tsakloglou and Antoninis 1999). In the course of trying to become more broadly-based, leftist parties also vie to attract middle-class voters who also prefer higher public education spending. Working middle-class parents are in favor of publicly provided full-time child care and university education. Core constituents of rightwing parties will support high public education expenditures if they can be convinced that such a policy generates higher tax revenues and lower social transfers in the future.

In contrast to direct income redistribution via the welfare system (social security, public health system or unemployment benefits), the entire electorate tends to benefit from a higher education level of the society. Leftwing parties that have moved to the right are therefore likely to focus exactly on education policy to attract voters from all societal groups: to be sure, their traditional constituency profits most from higher public education expenditures, but education policy is not likely to alienate other potential voters. Rightwing governments do not entirely adjust because they still favor private alternatives. In conclusion, my results suggest that education policy may well play a significant role in future policy debates.

\section{Acknowledgements}

I thank Georgios Chortareas, Heinrich Ursprung, two anonymous referees and the participants of the World Meeting of the Public Choice Society 2007 in Amsterdam for helpful comments and suggestions on earlier versions of the paper. Jakob Schwab and Carl Maier have provided excellent research assistance. 


\section{References}

Alesina, A. (1987). Macroeconomic policy in a two-party system as a repeated game. Quarterly Journal of Economics 102, 651-678.

Alesina, A., Roubini, N., \& Cohen G.D. (1997). Political cycles and the macroeconomy. The MIT Press, Cambridge.

Alt, J.E., Lassen, D.D. (2006). Fiscal transparency, political parties, and debt in OECD countries. European Economic Review 50, 1403-1439.

Angelopoulos, K. \& Economides, G. (2008). Fiscal policy, rent seeking, and growth under electoral uncertainty: theory and evidence from the OECD.

Canadian Journal of Economics 41, 1375-1405.

Ansell, B.W. (2008). University challenges explaining institutional change in higher education. World Politics 60, 189-230.

Arellano, M., \& Bond, S. (1991). Some Tests of Specification for Panel Data: Monte Carlo Evidence and an Application to Employment Equations. Review of Economic Studies 58, 277-297.

Beck, N., \& Katz, J.N. (1996). Nuisance vs. substance: Specifying and estimating time-series cross section models. Political Analysis 6, 1-36.

Behr, A. (2003). A comparison of dynamic panel data estimators: Monte Carlo evidence and an application to the investment function.

Discussion paper 05/03, Economic Research Centre of the Deutsche Bundesbank.

Bel., G., \& Elias-Moreno, F. (2009). Institutional determinants of military spending. Working Paper 2009/22, Research Institute of Applied Economics, Barcelona.

Bercoff, J. J., \& Meloni, O. (2009). Federal budget allocation in an emergent democracy: evidence from Argentina. Economics of Governance 10, 65-83.

Betts, J.R., \& Morrell, D. (1999). The determinants of undergraduate grade point average: The relative importance of family background, high school resources, and peer group effects. Journal of Human Resources 34, 268-293.

Bierbrauer, F. (2009). Optimal income taxation and public good provision with endogenous interest groups. Journal of Public Economic Theory 11, 311-342.

Bjørnskov, C. (2005). Does political ideology affect economic growth? Public Choice 123, 133-146.

Bjørnskov, C. (2008a). The growth-inequality association: government ideology matters. Journal of Development Economics 87, 300-308. 
Bjørnskov, C. (2008b). Political ideology and the structure of national accounts in the Nordic Countries, 1950-2004. Paper presented at the annual meeting of the European Public Choice Society, Jena 27-30 March 2008.

Bjørnskov, C., \& Potrafke, N. (2011a). Politics and privatization in Central and Eastern Europe: a panel data analysis. Economics of Transition, forthcoming.

Bjørnskov, C., \& Potrafke, N. (2011b). Political ideology and economic freedom across Canadian provinces. Eastern Economic Journal, forthcoming.

Bloom, D., Canning, D., Mansfield, R.K., \& Moore, M. (2007). Demographic change, social security systems, and savings. Journal of Monetary Economics 54, 92-114.

Blundell, R.W., \& Bond, S.R. (1998). Initial conditions and moment restrictions in dynamic Panel data models. Journal of Econometrics 87, 115-143.

Boix, C. (1997). Political parties and the supply side of the economy: The provision of Physical and human capital in advanced economies, 1960-90. American Journal of Political Science 1997 41, 814-845.

Boix, C. (1998). Political parties, growth and equality - Conservative and social democratic economic strategies in the world economy. Cambridge, Cambridge University Press.

Bräuninger, T. (2005). A partisan model of government expenditure.

Public Choice 125, 409-429.

Bruno, G.S.F. (2005a). Approximating the bias of the LSDV estimator for dynamic Unbalanced panel data models. Economics Letters 87, 361-366.

Bruno, G.S.F. (2005b). Estimation and inference in dynamic unbalanced panel data models With a small number of individuals. Stata Journal 5, 473-500.

Budge, I., Keman, H., \& Woldendorp, J. (1993). Political data 1945-1990. Party government in 20 democracies. European Journal of Political Research 24, 1-119.

Busemeyer, M.R. (2007). Determinants of public education spending in 21 OECD democracies, 1980-2001. Journal of European Public Policy 14, 582-610.

Busemeyer, M.R. (2009a). Social democrats and the new partisan politics of public Investment in education. Journal of European Public Policy 16, 107-126.

Busemeyer, M.R. (2009b). From myth to reality: globalization and public spending in OECD countries revisited. European Journal of Political Research 48, 455-482.

Calcagno, P.T., \& Escaleras, M. (2007). Party alternation, divided government, and fiscal performance within US states. Economics of Governance 8, 111-128.

Congleton, R.D., \& Bose, F. (2010). The rise of the modern welfare state, ideology, Institutions and income security: analysis and evidence. Public Choice 144, 535-555. 
Correa, H., \& Kim, J.-W. (1992). A causal analysis of defence expenditures of the USA and The USSR. Journal of Peace Research 29, 161-174.

Cremer, H., De Donder, P., \& Gahvari, F. (2008). Political competition within and between parties: an application to environmental policy. Journal of Public Economics 92, 532-547.

De Donder, P., \& Hindriks, J. (2007). Equilibrium social insurance with policy-motivated parties. European Journal of Political Economy 23, 624-640.

Drazen, A., \& Eslava, M. (2010). Electoral manipulation via voter-friendly spending: Theory and evidence. Journal of Development Economics 92, 39-52.

Dreher, A., (2006). Does globalization affect growth? Evidence from a new index of globalization. Applied Economics 38, 1091-1110.

Dreher, A., Sturm, J.-E., \& Ursprung, H.W. (2008a). The impact of globalization on the composition of government expenditures: Evidence from panel data. Public Choice 134, 263-292.

Dreher, A., Gaston, N., \& Martens, P. (2008b). Measuring globalization - Gauging its consequences. Berlin, Springer.

Gemmell, N., Kneller, R., \& Sanz, I., (2008). Foreign investment, international trade and the size and structure of public expenditures.

European Journal of Political Economy 24, 151-171.

Heckelman, J. C. (2002). Variable rational partisan business cycles: theory and some evidence. Canadian Journal of Economics 35, 568-585.

Henisz, W. (2000). The institutional environment for growth. Economics and Politics 12, 1-31.

Hibbs, D.A. Jr. (1977). Political parties and macroeconomic policy. American Political Science Review 71, 1467-1487.

Hicks, A.M., \& Swank, D. (1992). Politics, institutions and welfare spending in industrialized democracies, 1960-82.

American Political Science Review 86, 658-674.

Huber, E., \& Stephens, J.D. (2001). Development and crisis of the welfare state. Parties and policies in global markets. Chicago and London: University of Chicago Press.

Immergut, E.M. (1992). Health politics - Interests and institutions in Western Europe. Cambridge, Cambridge University Press.

Iversen, T., \& Stephens, J.D. (2008). Partisan politics, the welfare state, and three worlds of human capital formation. Comparative Political Studies 41, 600-637. 
Jensen, C. (2010). Issue compensation and right-wing social spending.

European Journal of Political Research 49, 282-299.

Jensen, C. (2011a). Marketization via compensation: health care and the politics of the right In advanced industrialized nations. British Journal of Political Science, forthcoming.

Jensen, C. (2011b). Determinants of welfare service provision after the Golden Age.

International Journal of Social Welfare, forthcoming.

Jensen, C. (2011c). Capitalist systems, de-industrialization, and the politics of public education. Comparative Political Studies, forthcoming.

Johansen, K., Mydland, Ø., \& B. Strøm (2007). Politics in wage setting: does government colour matter? Economics of Governance 8, 95-109.

Katsimi, M., \& Sarantides, V. (2010). Do elections affect the composition of fiscal policy? CESifo Working Papers No. 2908, Munich.

Kittel, B., \& Obinger, H. (2003). Politicial parties, institutions, and the dynamics of social expenditure in times of austerity. Journal of European Public Policy 10, 20-45.

Kneebone, R.D., \& McKenzie, K. J. (2001). Electoral and partisan cycles in fiscal policy: an examination of Canadian provinces.

International Tax and Public Finance 8, 753-774.

Lago-Peñas, I. \& Lago-Peñas, S. (2009). Does the nationalization of party systems affect the composition of public spending? Economics of Governance 10, 85-98.

Lange, P., \& Garrett, G. (1985). The politics of growth: strategic interaction and economic performance in advanced industrialized democracies, 1974-1980.

Journal of Politics 47, 792-827.

Laurency, P., \& Schindler, D. (2010). Why green parties should fear successful international climate agreements. TWI Discussion Papers No. 56, Kreuzlingen.

Merzyn, W., \& Ursprung, H.W. (2005). Voter support for privatizing education: evidence self-interest and ideology. European Journal of Political Economy 25, 33-58.

Newey, W.K., \& West, K.D. (1987). A simple, positive semi-definite, heteroskedasticity and autocorrelation consistent covariance matrix. Econometrica 55, 703-708.

Nincic, M., \& Cusack, T.R. (1979). The political economy of US military spending. Journal of Peace Research 16, 101-115.

Nordhaus, W. D. (1975). The political business cycle. Review of Economic Studies 42, 169-190. 
Oberndorfer, U., \& Steiner, V. (2007). Generationen- oder Parteienkonflikt? Eine empirische Analyse der deutschen Hochschulausgaben.

Perspektiven der Wirtschaftspolitik 8, 165-183.

OECD (2008). Main Economic Indicators. Paris.

Ono,T. (2009). The political economy of environmental and social security policies: the role of environmental lobbying. Economics of Governance 10, 261-296.

Pierson, P. (1996). The new politics of the welfare state. World Politics, 48, 143-179.

Pierson, P. (2001). Post-industrial pressures on the mature welfare states. In Pierson, P. (Eds.), The new politics of the welfare state. Oxford: Oxford University Press, 80-104.

Potrafke, N. (2009a). Did globalization restrict partisan politics? An empirical evaluation of social expenditures in a panel of OECD countries. Public Choice 140, 105-124.

Potrafke, N. (2009b). Does government ideology influence political alignment with the U.S.? An empirical analysis of voting in the UN General Assembly.

Review of International Organizations 4, 245-268.

Potrafke, N. (2010a). The growth of public health expenditures in OECD countries: do government ideology and electoral motives matter?

Journal of Health Economics 29, 797-810.

Potrafke N (2010b) Does government ideology influence deregulation of product markets? Empirical evidence from OECD countries. Public Choice 143, 135-155.

Potrafke, N. (2010c). Ideology and cultural policy. TWI Discussion Papers No. 49, Kreuzlingen.

Potrafke, N. (2011a). Public expenditures on education and cultural affairs in the West German states: does government ideology influence the budget composition? German Economic Review 12, 124-145.

Potrafke, N. (2011b). Political cycles and economic performance in OECD countries: empirical evidence from 1951-2006. Public Choice, forthcoming.

Rogoff, K \& Sibert, A. (1988). Elections and macroeconomic policy cycles. Review of Economic Studies 55, 1-16.

Roodman, D. (2009). A note on the theme of too many instruments. Oxford Bulletin of Economics and Statistics 71, 135-158.

Roodman, D. (2006). How to do xtabond2: An introduction to "Difference" and "System" GMM in Stata. Center for Global Development. Working Paper 103.

Rose, R. (1990). Inheritance before choice in public policy. Journal of Theoretical Politics 2, 263-291. 
Sakamoto, T. (2008). Economic policy and performance in industrial democracies - party governments, central banks and the fiscal-monetary policy mix. Routledge, London and New York.

Sanz, I., \& Velázquez, F. (2007). The role of aging in the growth of government and social welfare spending in the OECD.

European Journal of Political Economy 23, 917-931.

Schmidt, M.G. (2007). Testing the retrenchment hypothesis: education spending, 1960-2002. In Castles, F.G. (eds.). The disappearing state? Retrenchment realities in an age of globalization. Celtenham: Edward Elgar, 159-183.

Schneider, C., \& Urpelainen, J. (2010). Partisan waves in international coorperation. Working Paper, University of California, San Diego.

Schulze, G.G., \& Rose, A. (1998). Public orchestra funding in Germany - an empirical investigation. Journal of Cultural Economics 22, 227-247.

Schulze, G.G., \& Ursprung, H.W. (1999). Globalisation of the economy and the nation state. World Economy 22, 295-352.

Schulze, G.G., \& Ursprung, H.W. (2000). La donna e mobile - or is she? Voter preferences and public support for the performing arts.

Public Choice 102, 131-149.

Shelton, C.A. (2007). The size and composition of government expenditure. Journal of Public Economics 91, 2230-2260.

Shi, M. \& Svensson, J. (2006). Political budget cycles: do they differ across countries and why? Journal of Public Economics 90, 1367-1389.

Stock, J.H., \& Watson, M.W. (2008). Heteroskedasticity-robust standard errors for fixed-effects panel-data regression. Econometrica 76, 155-174.

Sylwester, K. (2002). Can education expenditures reduce income inequality? Economics of Education Review 21, 43-52.

Tavares, J. (2004). Does right or left matter? Cabinets, credibility and fiscal adjustment. Journal of Public Economics 88, 2447-2468.

Tepe, M. \& Vanhuysse, P. (2009a). Educational business cycles - The political economy of teacher hiring across German states, 1992-2004. Public Choice 139, 61-82.

Tepe, M. \& Vanhuysse, P. (2009b). Are aging OECD welfare states on the path to gerontocracy? Evidence from 18 democracies, 1980-2002. Journal of Public Policy 29, 1-28. 
Tepe, M. \& Vanhuysse, P. (2010). Who cuts back and when? The politics of delays in social expenditure cutbacks, 1980-2005. West European Politics 33, 1214-1240.

Tridimas, G. (2001). The economics and politics of the structure of public expenditure. Public Choice 106, 299-316.

Tsakloglou, P., \& Antoninis. M. (1999). On the distributional impact of public education: evidence from Greece. Economics of Education Review 18, 439-452.

Ursprung, H. W. (2008). Globalisation and the welfare state. In Durlauf, S. N. \& Blume, L. (eds.). The New Palgrave Dictionary of Economics, Second edition. Köln: Palgrave Macmillan.

Vergne, C. (2009). Democracy, elections and allocation of public expenditures in developing countries European Journal of Political Economy 25, 63-77.

Woldendorp, J., Keman, H., \& Budge, I. (1998). Party government in 20 democracies: an update 1990-1995. European Journal of Political Research 33, 125-164.

Woldendorp, J., Keman, H., \& Budge, I. (2000). Party government in 48 democracies 1945-1998: composition, duration, personnel.

Dordrecht, Kluwer Academic Publishers.

Wooldridge, J. M. (2002). Econometric analysis of cross section and panel data. Cambridge, MIT Press.

World Bank (2007). World Development Indicators. Washington, D. C.

World Bank (2008). World Development Indicators. Washington, D. C. 
Table 1: Regression Results. 1970-1997. Dynamic bias corrected estimator. Dependent variable: Growth rates of the expenditure categories (measured as a share of GDP).

\begin{tabular}{|c|c|c|c|c|c|c|c|c|c|c|}
\hline & $\begin{array}{l}\text { (1) } \\
\text { Public sector } \\
\text { size }\end{array}$ & Public services & Defense & $\begin{array}{c}(4) \\
\text { Economic } \\
\text { services }\end{array}$ & $\begin{array}{c}\text { (5) } \\
\begin{array}{c}\text { Transport and } \\
\text { communica- } \\
\text { tions }\end{array} \\
\end{array}$ & $\begin{array}{c}\text { (6) } \\
\text { Housing }\end{array}$ & $\begin{array}{c}\text { (7) } \\
\text { Health }\end{array}$ & $\begin{array}{c}\text { (8) } \\
\text { Cultural affairs }\end{array}$ & $\begin{array}{c}\text { (9) } \\
\text { Education }\end{array}$ & Social welfare \\
\hline Ideology (leftwing) & $\begin{array}{l}0.0025 \\
{[1.17]}\end{array}$ & $\begin{array}{c}0.0113^{* *} \\
{[2.47]}\end{array}$ & $\begin{array}{l}0.0054 \\
{[1.16]}\end{array}$ & $\begin{array}{c}-0.0002 \\
{[0.03]}\end{array}$ & $\begin{array}{c}0.0061 \\
{[0.91]}\end{array}$ & $\begin{array}{l}0.0209 \\
{[1.49]}\end{array}$ & $\begin{array}{c}-0.0013 \\
{[0.40]}\end{array}$ & $\begin{array}{l}0.0013 \\
{[0.23]}\end{array}$ & $\begin{array}{l}0.0003 \\
{[0.12]}\end{array}$ & $\begin{array}{c}-0.0013 \\
{[0.47]}\end{array}$ \\
\hline$\Delta \ln$ Total population & $\begin{array}{l}0.6509 \\
{[1.17]}\end{array}$ & $\begin{array}{l}0.4557 \\
{[0.39]}\end{array}$ & $\begin{array}{l}0.0914 \\
{[0.08]}\end{array}$ & $\begin{array}{c}3.1941^{*} \\
{[1.96]}\end{array}$ & $\begin{array}{l}0.3955 \\
{[0.23]}\end{array}$ & $\begin{array}{c}4.3578 \\
{[1.20]}\end{array}$ & $\begin{array}{c}-0.2486 \\
{[0.30]}\end{array}$ & $\begin{array}{l}0.3256 \\
{[0.21]}\end{array}$ & $\begin{array}{l}0.1076 \\
{[0.15]}\end{array}$ & $\begin{array}{c}0.4788 \\
{[0.64]}\end{array}$ \\
\hline$\Delta \ln$ Young share & $\begin{array}{c}-0.0818 \\
{[0.41]}\end{array}$ & $\begin{array}{c}0.2642 \\
{[0.64]}\end{array}$ & $\begin{array}{c}-0.0641 \\
{[0.15]}\end{array}$ & $\begin{array}{c}-1.7855^{* * * *} \\
{[2.94]}\end{array}$ & $\begin{array}{c}-0.4212 \\
{[0.66]}\end{array}$ & $\begin{array}{c}-0.2586 \\
{[0.20]}\end{array}$ & $\begin{array}{c}-0.1414 \\
{[0.47]}\end{array}$ & $\begin{array}{c}0.0493 \\
{[0.09]}\end{array}$ & $\begin{array}{c}0.2136 \\
{[0.84]}\end{array}$ & $\begin{array}{c}0.1981 \\
{[0.77]}\end{array}$ \\
\hline$\Delta$ ln Elderly share & $\begin{array}{c}-0.4475^{* *} \\
{[2.04]}\end{array}$ & $\begin{array}{c}-0.1608 \\
{[0.36]}\end{array}$ & $\begin{array}{l}-0.491 \\
{[1.05]}\end{array}$ & $\begin{array}{c}-0.8404 \\
{[1.33]}\end{array}$ & $\begin{array}{c}-0.8564 \\
{[1.27]}\end{array}$ & $\begin{array}{c}-1.6038 \\
{[1.14]}\end{array}$ & $\begin{array}{c}-0.4146 \\
{[1.28]}\end{array}$ & $\begin{array}{c}-0.1543 \\
{[0.26]}\end{array}$ & $\begin{array}{c}-0.5115^{*} \\
{[1.78]}\end{array}$ & $\begin{array}{c}-0.3921 \\
{[1.33]}\end{array}$ \\
\hline$\Delta$ ln Per capita income & $\begin{array}{c}-0.8431 * * * \\
{[7.42]}\end{array}$ & $\begin{array}{c}-0.9910^{* * *} \\
{[4.27]}\end{array}$ & $\begin{array}{c}-0.7350 * * * \\
{[3.05]}\end{array}$ & $\begin{array}{c}-0.9623 * * * \\
{[2.96]}\end{array}$ & $\begin{array}{c}-0.5413 \\
{[1.57]}\end{array}$ & $\begin{array}{c}-1.2552^{*} \\
{[1.74]}\end{array}$ & $\begin{array}{c}-0.7003 * * * \\
{[4.21]}\end{array}$ & $\begin{array}{l}-0.078 \\
{[0.26]}\end{array}$ & $\begin{array}{c}-0.7231 * * * \\
{[4.99]}\end{array}$ & $\begin{array}{c}-1.0264 * * * \\
{[6.79]}\end{array}$ \\
\hline$\Delta \ln$ Trade (as a share of GDP) & $\begin{array}{c}-0.0381 \\
{[1.08]}\end{array}$ & $\begin{array}{c}-0.0719 \\
{[1.00]}\end{array}$ & $\begin{array}{c}-0.0762 \\
{[1.02]}\end{array}$ & $\begin{array}{c}-0.0605 \\
{[0.60]}\end{array}$ & $\begin{array}{c}-0.1150 \\
{[1.07]}\end{array}$ & $\begin{array}{l}0.0176 \\
{[0.08]}\end{array}$ & $\begin{array}{c}-0.0442 \\
{[0.86]}\end{array}$ & $\begin{array}{l}-0.09 \\
{[0.94]}\end{array}$ & $\begin{array}{c}-0.1287 * * * \\
{[2.85]}\end{array}$ & $\begin{array}{c}-0.0754 \\
{[1.61]}\end{array}$ \\
\hline$\Delta \ln$ Prices public consumption & $\begin{array}{c}0.1284 * * * \\
{[2.83]}\end{array}$ & $\begin{array}{l}0.1300 \\
{[1.40]}\end{array}$ & $\begin{array}{c}-0.0610 \\
{[0.61]}\end{array}$ & $\begin{array}{l}0.1946 \\
{[1.49]}\end{array}$ & $\begin{array}{l}0.0191 \\
{[0.14]}\end{array}$ & $\begin{array}{l}0.1277 \\
{[0.44]}\end{array}$ & $\begin{array}{c}0.3059 * * * \\
{[4.64]}\end{array}$ & $\begin{array}{l}0.0360 \\
{[0.29]}\end{array}$ & $\begin{array}{c}0.1776^{* * * *} \\
{[3.00]}\end{array}$ & $\begin{array}{l}0.0421 \\
{[0.68]}\end{array}$ \\
\hline$\Delta \ln$ Unemployment & $\begin{array}{c}0.0149^{*} \\
{[1.81]}\end{array}$ & $\begin{array}{c}-0.0308^{*} \\
{[1.86]}\end{array}$ & $\begin{array}{l}0.0241 \\
{[1.39]}\end{array}$ & $\begin{array}{c}0.0592 * * \\
{[2.52]}\end{array}$ & $\begin{array}{l}0.0321 \\
{[1.29]}\end{array}$ & $\begin{array}{c}-0.0018 \\
{[0.04]}\end{array}$ & $\begin{array}{l}0.0038 \\
{[0.32]}\end{array}$ & $\begin{array}{l}0.0271 \\
{[1.24]}\end{array}$ & $\begin{array}{c}-0.0011 \\
{[0.10]}\end{array}$ & $\begin{array}{l}0.0007 \\
{[0.06]}\end{array}$ \\
\hline Lagged dependent variable & $\begin{array}{l}0.0165 \\
{[0.33]}\end{array}$ & $\begin{array}{l}0.0325 \\
{[0.63]}\end{array}$ & $\begin{array}{c}-0.1131^{* *} \\
{[2.26]}\end{array}$ & $\begin{array}{c}-0.0792 \\
{[1.55]}\end{array}$ & $\begin{array}{l}0.0265 \\
{[0.51]}\end{array}$ & $\begin{array}{c}-0.1364 * * * \\
{[2.88]}\end{array}$ & $\begin{array}{c}-0.0030 \\
{[0.06]}\end{array}$ & $\begin{array}{c}-0.0067 \\
{[0.15]}\end{array}$ & $\begin{array}{c}0.1027 * * \\
{[2.27]}\end{array}$ & $\begin{array}{c}0.1864 * * * \\
{[4.00]}\end{array}$ \\
\hline $\begin{array}{l}\text { Fixed country effects } \\
\text { Fixed period effects }\end{array}$ & $\begin{array}{l}\text { Yes } \\
\text { Yes }\end{array}$ & $\begin{array}{l}\text { Yes } \\
\text { Yes }\end{array}$ & $\begin{array}{l}\text { Yes } \\
\text { Yes }\end{array}$ & $\begin{array}{l}\text { Yes } \\
\text { Yes }\end{array}$ & $\begin{array}{l}\text { Yes } \\
\text { Yes }\end{array}$ & $\begin{array}{l}\text { Yes } \\
\text { Yes }\end{array}$ & $\begin{array}{l}\text { Yes } \\
\text { Yes }\end{array}$ & $\begin{array}{l}\text { Yes } \\
\text { Yes }\end{array}$ & $\begin{array}{l}\text { Yes } \\
\text { Yes }\end{array}$ & $\begin{array}{l}\text { Yes } \\
\text { Yes }\end{array}$ \\
\hline Observations & 552 & 552 & 552 & 552 & 552 & 552 & 552 & 552 & 552 & 552 \\
\hline Number of countries & 23 & 23 & 23 & 23 & 23 & 23 & 23 & 23 & 23 & 23 \\
\hline
\end{tabular}

Notes: Absolute value of $t$ statistics in brackets; * significant at $10 \% ; * *$ significant at $5 \% ; * * *$ significant at $1 \%$ 
Table 2: Regression Results. 1990-2006. Dynamic bias corrected estimator. Dependent variable: Growth rates of the expenditure categories (measured as a share of GDP).

\begin{tabular}{|c|c|c|c|c|c|c|c|c|c|c|}
\hline & $\begin{array}{c}(1) \\
\text { Public sector } \\
\text { size }\end{array}$ & $\begin{array}{c}\text { (2) } \\
\text { Public services }\end{array}$ & $\begin{array}{c}\text { (3) } \\
\text { Defense }\end{array}$ & $\begin{array}{c}(4) \\
\text { Economic } \\
\text { services } \\
\end{array}$ & $\begin{array}{c}(5) \\
\text { Environmental } \\
\text { protection }\end{array}$ & $\begin{array}{c}(6) \\
\text { Housing }\end{array}$ & $\begin{array}{c}(7) \\
\text { Health }\end{array}$ & $\begin{array}{c}\text { (8) } \\
\text { Cultural affairs }\end{array}$ & $\begin{array}{c}\text { (9) } \\
\text { Education }\end{array}$ & $\begin{array}{c}\text { (10) } \\
\text { Social welfare }\end{array}$ \\
\hline Ideology (leftwing) & $\begin{array}{c}-0.0003 \\
{[0.13]}\end{array}$ & $\begin{array}{c}-0.0058 \\
{[0.95]}\end{array}$ & $\begin{array}{l}0.0020 \\
{[0.26]}\end{array}$ & $\begin{array}{l}0.0098 \\
{[0.85]}\end{array}$ & $\begin{array}{c}-0.0041 \\
{[0.43]}\end{array}$ & $\begin{array}{l}0.0015 \\
{[0.08]}\end{array}$ & $\begin{array}{c}0.0003 \\
{[0.09]}\end{array}$ & $\begin{array}{l}0.0081 \\
{[1.32]}\end{array}$ & $\begin{array}{c}0.0075^{* * *} \\
{[2.61]}\end{array}$ & $\begin{array}{c}-0.0017 \\
{[0.67]}\end{array}$ \\
\hline$\Delta \ln$ Total population & $\begin{array}{c}-1.4304 \\
{[1.59]}\end{array}$ & $\begin{array}{c}-1.3289 \\
{[0.58]}\end{array}$ & $\begin{array}{l}0.1248 \\
{[0.04]}\end{array}$ & $\begin{array}{l}5.9995 \\
{[1.41]}\end{array}$ & $\begin{array}{c}-0.9838 \\
{[0.28]}\end{array}$ & $\begin{array}{c}12.0662^{*} \\
{[1.83]}\end{array}$ & $\begin{array}{c}-3.5357^{* *} * \\
{[2.55]}\end{array}$ & $\begin{array}{c}-3.7760^{*} \\
{[1.68]}\end{array}$ & $\begin{array}{c}-0.9898 \\
{[0.95]}\end{array}$ & $\begin{array}{c}-2.7158^{* * * *} \\
{[2.86]}\end{array}$ \\
\hline$\Delta \ln$ Young share & $\begin{array}{l}0.5381 \\
{[1.17]}\end{array}$ & $\begin{array}{l}1.5749 \\
{[1.37]}\end{array}$ & $\begin{array}{c}-2.3701 * \\
{[1.67]}\end{array}$ & $\begin{array}{c}-2.8429 \\
{[1.33]}\end{array}$ & $\begin{array}{c}-1.7712 \\
{[0.99]}\end{array}$ & $\begin{array}{c}-6.7583^{* *} \\
{[2.02]}\end{array}$ & $\begin{array}{l}0.8202 \\
{[1.15]}\end{array}$ & $\begin{array}{c}-0.5274 \\
{[0.47]}\end{array}$ & $\begin{array}{l}0.0001 \\
{[0.00]}\end{array}$ & $\begin{array}{c}1.2583 * * * \\
{[2.61]}\end{array}$ \\
\hline$\Delta$ ln Elderly share & $\begin{array}{l}0.0351 \\
{[1.41]}\end{array}$ & $\begin{array}{c}0.0578 \\
{[0.91]}\end{array}$ & $\begin{array}{c}0.0099 \\
{[0.13]}\end{array}$ & $\begin{array}{c}0.2317 * * \\
{[1.97]}\end{array}$ & $\begin{array}{l}0.0776 \\
{[0.79]}\end{array}$ & $\begin{array}{c}-0.0149 \\
{[0.08]}\end{array}$ & $\begin{array}{c}-0.0165 \\
{[0.43]}\end{array}$ & $\begin{array}{l}0.0224 \\
{[0.36]}\end{array}$ & $\begin{array}{c}0.0037 \\
{[0.13]}\end{array}$ & $\begin{array}{c}-0.0237 \\
{[0.90]}\end{array}$ \\
\hline$\Delta \ln$ Per capita income & $\begin{array}{c}-1.0432 * * * \\
{[4.90]}\end{array}$ & $\begin{array}{c}-1.3503^{* *} \\
{[2.48]}\end{array}$ & $\begin{array}{c}-3.0397 * * * \\
{[4.70]}\end{array}$ & $\begin{array}{c}-0.5571 \\
{[0.56]}\end{array}$ & $\begin{array}{c}-0.6939 \\
{[0.85]}\end{array}$ & $\begin{array}{l}0.0379 \\
{[0.02]}\end{array}$ & $\begin{array}{c}-1.1779 * * * \\
{[3.66]}\end{array}$ & $\begin{array}{c}-0.7585 \\
{[1.47]}\end{array}$ & $\begin{array}{c}-0.7406^{* * * *} \\
{[3.04]}\end{array}$ & $\begin{array}{c}-0.9065^{* * * *} \\
{[4.12]}\end{array}$ \\
\hline$\Delta \ln$ Trade (as a share of GDP) & $\begin{array}{l}0.0075 \\
{[0.14]}\end{array}$ & $\begin{array}{l}0.1066 \\
{[0.75]}\end{array}$ & $\begin{array}{c}0.4418^{* * *} \\
{[2.57]}\end{array}$ & $\begin{array}{l}0.1181 \\
{[0.45]}\end{array}$ & $\begin{array}{c}-0.2709 \\
{[1.25]}\end{array}$ & $\begin{array}{c}-0.0017 \\
{[0.00]}\end{array}$ & $\begin{array}{c}-0.2195^{* * *} * \\
{[2.59]}\end{array}$ & $\begin{array}{c}-0.3002^{* *} \\
{[2.20]}\end{array}$ & $\begin{array}{c}-0.0808 \\
{[1.26]}\end{array}$ & $\begin{array}{c}-0.0299 \\
{[0.51]}\end{array}$ \\
\hline$\Delta \ln$ Prices public consumption & $\begin{array}{c}0.4585^{* * * *} \\
{[2.93]}\end{array}$ & $\begin{array}{l}0.5516 \\
{[1.39]}\end{array}$ & $\begin{array}{l}0.5127 \\
{[1.09]}\end{array}$ & $\begin{array}{l}1.0652 \\
{[1.46]}\end{array}$ & $\begin{array}{c}2.0419^{* * * *} \\
{[3.41]}\end{array}$ & $\begin{array}{l}1.3184 \\
{[1.16]}\end{array}$ & $\begin{array}{l}0.1361 \\
{[0.57]}\end{array}$ & $\begin{array}{l}0.5006 \\
{[1.31]}\end{array}$ & $\begin{array}{c}0.4706^{* * * *} \\
{[2.63]}\end{array}$ & $\begin{array}{l}0.1552 \\
{[0.95]}\end{array}$ \\
\hline$\Delta \ln$ Unemployment & $\begin{array}{c}-0.0056 \\
{[0.22]}\end{array}$ & $\begin{array}{c}-0.0529 \\
{[0.83]}\end{array}$ & $\begin{array}{l}-0.061 \\
{[0.79]}\end{array}$ & $\begin{array}{l}0.0367 \\
{[0.31]}\end{array}$ & $\begin{array}{c}-0.1158 \\
{[1.18]}\end{array}$ & $\begin{array}{l}0.1904 \\
{[1.04]}\end{array}$ & $\begin{array}{c}-0.1038^{* * * *} \\
{[2.73]}\end{array}$ & $\begin{array}{c}-0.0054 \\
{[0.09]}\end{array}$ & $\begin{array}{c}-0.0036 \\
{[0.13]}\end{array}$ & $\begin{array}{l}0.0341 \\
{[1.32]}\end{array}$ \\
\hline Lagged dependent variable & $\begin{array}{c}-0.1446^{* * *} \\
{[2.71]}\end{array}$ & $\begin{array}{c}-0.2005^{* * *} \\
{[3.58]}\end{array}$ & $\begin{array}{c}-0.0465 \\
{[0.85]}\end{array}$ & $\begin{array}{c}-0.4374 * * * \\
{[7.47]}\end{array}$ & $\begin{array}{c}-0.0928^{*} \\
{[1.82]}\end{array}$ & $\begin{array}{c}-0.1941 * * * \\
{[3.70]}\end{array}$ & $\begin{array}{l}0.0226 \\
{[0.38]}\end{array}$ & $\begin{array}{c}-0.0702 \\
{[1.08]}\end{array}$ & $\begin{array}{c}-0.0221 \\
{[0.38]}\end{array}$ & $\begin{array}{l}0.0338 \\
{[0.65]}\end{array}$ \\
\hline $\begin{array}{l}\text { Fixed country effects } \\
\text { Fixed period effects }\end{array}$ & $\begin{array}{l}\text { Yes } \\
\text { Yes }\end{array}$ & $\begin{array}{l}\text { Yes } \\
\text { Yes } \\
\end{array}$ & $\begin{array}{l}\text { Yes } \\
\text { Yes } \\
\end{array}$ & $\begin{array}{l}\text { Yes } \\
\text { Yes } \\
\end{array}$ & $\begin{array}{l}\text { Yes } \\
\text { Yes } \\
\end{array}$ & $\begin{array}{l}\text { Yes } \\
\text { Yes } \\
\end{array}$ & $\begin{array}{l}\text { Yes } \\
\text { Yes } \\
\end{array}$ & $\begin{array}{l}\text { Yes } \\
\text { Yes }\end{array}$ & $\begin{array}{l}\text { Yes } \\
\text { Yes } \\
\end{array}$ & $\begin{array}{l}\text { Yes } \\
\text { Yes }\end{array}$ \\
\hline $\begin{array}{l}\text { Observations } \\
\text { Number of countries }\end{array}$ & $\begin{array}{c}247 \\
20\end{array}$ & $\begin{array}{c}247 \\
20\end{array}$ & $\begin{array}{c}247 \\
20\end{array}$ & $\begin{array}{c}247 \\
20\end{array}$ & $\begin{array}{c}247 \\
20\end{array}$ & $\begin{array}{c}247 \\
20\end{array}$ & $\begin{array}{c}247 \\
20\end{array}$ & $\begin{array}{c}247 \\
20\end{array}$ & $\begin{array}{c}247 \\
20\end{array}$ & $\begin{array}{c}247 \\
20\end{array}$ \\
\hline
\end{tabular}

Notes: Absolute value of $\mathrm{t}$ statistics in brackets; * significant at 10\%; $* *$ significant at $5 \%$; ** significant at $1 \%$ 
Table 3: Regression Results. 1970-1997. Error Correction Model.

Dynamic bias corrected estimator. Dependent variable: First differences of the expenditure categories (measured as a share of GDP).

\begin{tabular}{|c|c|c|c|c|c|c|c|c|c|c|}
\hline & $\begin{array}{l}\text { (1) } \\
\text { Public sector } \\
\text { size }\end{array}$ & Public services & Defense & $\begin{array}{c}\text { (4) } \\
\text { Economic } \\
\text { services }\end{array}$ & $\begin{array}{c}\text { (5) } \\
\text { Transport and } \\
\text { communica- } \\
\text { tions }\end{array}$ & Housing & Health & Cultural affairs & Education & Social welfare \\
\hline Ideology (leftwing) t-1 & $\begin{array}{l}0.0367 \\
{[0.32]}\end{array}$ & $\begin{array}{l}0.0290 \\
{[1.47]}\end{array}$ & $\begin{array}{l}0.0015 \\
{[0.13]}\end{array}$ & $\begin{array}{l}0.0209 \\
{[0.41]}\end{array}$ & $\begin{array}{c}0.0129 \\
{[0.65]}\end{array}$ & $\begin{array}{l}0.0051 \\
{[0.35]}\end{array}$ & $\begin{array}{c}-0.0026 \\
{[0.12]}\end{array}$ & $\begin{array}{c}-0.0024 \\
{[0.42]}\end{array}$ & $\begin{array}{c}-0.0142 \\
{[0.83]}\end{array}$ & $\begin{array}{c}-0.0276 \\
{[0.66]}\end{array}$ \\
\hline$\Delta$ Ideology (leftwing) & $\begin{array}{l}-0.031 \\
{[0.25]}\end{array}$ & $\begin{array}{l}0.0279 \\
{[1.30]}\end{array}$ & $\begin{array}{l}0.0047 \\
{[0.36]}\end{array}$ & $\begin{array}{c}-0.0624 \\
{[1.15]}\end{array}$ & $\begin{array}{c}0.0365^{*} \\
{[1.70]}\end{array}$ & $\begin{array}{l}0.0001 \\
{[0.00]}\end{array}$ & $\begin{array}{c}-0.0133 \\
{[0.56]}\end{array}$ & $\begin{array}{c}-0.0014 \\
{[0.23]}\end{array}$ & $\begin{array}{l}-0.018 \\
{[0.97]}\end{array}$ & $\begin{array}{c}-0.0565 \\
{[1.25]}\end{array}$ \\
\hline Total population $\mathrm{t}-1$ & $\begin{array}{l}4 \times 10^{-5} \\
{[1.48]}\end{array}$ & $\begin{array}{l}2 \times 10^{-6} \\
{[0.38]}\end{array}$ & $\begin{array}{c}6 \times 10^{-6 * *} \\
{[2.07]}\end{array}$ & $\begin{array}{l}2 \times 10^{-5} \\
{[1.35]}\end{array}$ & $\begin{array}{l}4 \times 10^{-6} \\
{[0.96]}\end{array}$ & $\begin{array}{l}2 \times 10^{-7} \\
{[0.06]}\end{array}$ & $\begin{array}{l}5 \times 10^{-7} \\
{[0.10]}\end{array}$ & $\begin{array}{l}2 \times 10^{-7} \\
00.17]\end{array}$ & $\begin{array}{c}-3 \times 10^{-7} \\
{[0.08]}\end{array}$ & $\begin{array}{l}5 \times 10^{-6} \\
{[0.54]}\end{array}$ \\
\hline$\Delta$ Total population & $\begin{array}{c}-0.0011 \\
{[1.33]}\end{array}$ & $\begin{array}{c}-0.0001 \\
{[0.59]}\end{array}$ & $\begin{array}{c}-0.0002^{* *} \\
{[2.14]}\end{array}$ & $\begin{array}{c}-0.0004 \\
{[1.07]}\end{array}$ & $\begin{array}{c}-0.0001 \\
{[0.45]}\end{array}$ & $\begin{array}{l}1 \times 10^{-6} \\
{[0.01]}\end{array}$ & $\begin{array}{c}-1 \times 10^{-5} \\
{[0.09]}\end{array}$ & $\begin{array}{l}1 \times 10^{-5} \\
{[0.29]}\end{array}$ & $\begin{array}{l}4 \times 10^{-5} \\
{[0.28]}\end{array}$ & $\begin{array}{c}-0.0001 \\
{[0.27]}\end{array}$ \\
\hline Young share $\mathrm{t}-1$ & $\begin{array}{c}-0.0345 \\
{[0.31]}\end{array}$ & $\begin{array}{l}0.0172 \\
{[0.91]}\end{array}$ & $\begin{array}{c}-0.0051 \\
{[0.43]}\end{array}$ & $\begin{array}{c}-0.0125 \\
{[0.26]}\end{array}$ & $\begin{array}{l}0.0072 \\
{[0.38]}\end{array}$ & $\begin{array}{l}-0.005 \\
{[0.36]}\end{array}$ & $\begin{array}{c}-0.0006 \\
{[0.03]}\end{array}$ & $\begin{array}{c}-0.0033 \\
{[0.59]}\end{array}$ & $\begin{array}{l}0.0008 \\
{[0.05]}\end{array}$ & $\begin{array}{c}-0.0477 \\
{[1.18]}\end{array}$ \\
\hline$\Delta$ Young share & $\begin{array}{l}0.2214 \\
{[0.39]}\end{array}$ & $\begin{array}{l}0.0924 \\
{[0.95]}\end{array}$ & $\begin{array}{l}0.0349 \\
{[0.60]}\end{array}$ & $\begin{array}{c}-0.3422 \\
{[1.36]}\end{array}$ & $\begin{array}{c}-0.0844 \\
{[0.85]}\end{array}$ & $\begin{array}{l}0.029 \\
{[0.41]}\end{array}$ & $\begin{array}{l}0.0274 \\
{[0.26]}\end{array}$ & $\begin{array}{l}0.0002 \\
{[0.01]}\end{array}$ & $\begin{array}{c}0.0034 \\
{[0.04]}\end{array}$ & $\begin{array}{l}0.1361 \\
{[0.67]}\end{array}$ \\
\hline Elderly share $\mathrm{t}-1$ & $\begin{array}{c}-0.0528 \\
{[0.30]}\end{array}$ & $\begin{array}{l}0.0011 \\
{[0.04]}\end{array}$ & $\begin{array}{c}-0.0190 \\
{[1.03]}\end{array}$ & $\begin{array}{c}-0.0602 \\
{[0.80]}\end{array}$ & $\begin{array}{l}0.0027 \\
{[0.09]}\end{array}$ & $\begin{array}{c}-0.0113 \\
{[0.52]}\end{array}$ & $\begin{array}{c}0.0216 \\
{[0.66]}\end{array}$ & $\begin{array}{c}-0.0052 \\
{[0.61]}\end{array}$ & $\begin{array}{c}-0.0021 \\
{[0.08]}\end{array}$ & $\begin{array}{c}0.0075 \\
{[0.12]}\end{array}$ \\
\hline$\Delta$ Elderly share & $\begin{array}{c}-1.3582^{*} \\
{[1.68]}\end{array}$ & $\begin{array}{c}-0.0719 \\
{[0.51]}\end{array}$ & $\begin{array}{c}-0.1237 \\
{[1.46]}\end{array}$ & $\begin{array}{c}-0.5598 \\
{[1.57]}\end{array}$ & $\begin{array}{c}-0.2704^{*} \\
{[1.94]}\end{array}$ & $\begin{array}{c}-0.1556 \\
{[1.53]}\end{array}$ & $\begin{array}{c}-0.0130 \\
{[0.08]}\end{array}$ & $\begin{array}{c}-0.0124 \\
{[0.31]}\end{array}$ & $\begin{array}{c}-0.1803 \\
{[1.51]}\end{array}$ & $\begin{array}{c}-0.3312 \\
{[1.13]}\end{array}$ \\
\hline Per capita income t-1 & $\begin{array}{l}0.0001 \\
{[1.15]}\end{array}$ & $\begin{array}{l}1 \times 10^{-5} \\
{[1.35]}\end{array}$ & $\begin{array}{c}-5 \times 10^{-6} \\
{[0.86]}\end{array}$ & $\begin{array}{c}-3 \times 10^{-6} \\
{[0.15]}\end{array}$ & $\begin{array}{l}4 \times 10^{-6} \\
{[0.39]}\end{array}$ & $\begin{array}{l}5 \times 10^{-6} \\
{[0.73]}\end{array}$ & $\begin{array}{l}2 \times 10^{-6} \\
{[0.19]}\end{array}$ & $\begin{array}{c}5 \times 10^{-6} * \\
{[1.77]}\end{array}$ & $\begin{array}{l}9 \times 10^{-6} \\
{[1.05]}\end{array}$ & $\begin{array}{l}3 \times 10^{-5} \\
{[1.45]}\end{array}$ \\
\hline$\Delta$ Per capita income & $\begin{array}{c}-0.0015^{* * *} \\
{[6.45]}\end{array}$ & $\begin{array}{c}-0.0001^{* * *} \\
{[2.75]}\end{array}$ & $\begin{array}{c}-0.0001 * * * \\
{[2.71]}\end{array}$ & $\begin{array}{c}-0.0003 * * * \\
{[2.73]}\end{array}$ & $\begin{array}{c}-0.0002 * * * \\
{[4.03]}\end{array}$ & $\begin{array}{c}-0.0001^{* *} \\
{[2.16]}\end{array}$ & $\begin{array}{c}-0.0001 * * * \\
{[3.31]}\end{array}$ & $\begin{array}{c}-1 \times 10^{-5} \\
{[0.97]}\end{array}$ & $\begin{array}{c}-0.0001 * * * \\
{[3.59]}\end{array}$ & $\begin{array}{c}-0.0005^{* * *} \\
{[5.80]}\end{array}$ \\
\hline Trade (as a share of GDP) $t-1$ & $\begin{array}{c}-0.0156 \\
{[0.85]}\end{array}$ & $\begin{array}{l}9 \times 10^{-6} \\
{[0.00]}\end{array}$ & $\begin{array}{c}-0.0016 \\
{[0.83]}\end{array}$ & $\begin{array}{l}0.0016 \\
{[0.21]}\end{array}$ & $\begin{array}{r}0.0003 \\
{[0.08]}\end{array}$ & $\begin{array}{l}0.0024 \\
{[1.05]}\end{array}$ & $\begin{array}{c}-0.0005 \\
{[0.16]}\end{array}$ & $\begin{array}{c}-3 \times 10^{-5} \\
{[0.04]}\end{array}$ & $\begin{array}{c}-0.0053^{*} \\
{[1.95]}\end{array}$ & $\begin{array}{c}-0.0106 \\
{[1.56]}\end{array}$ \\
\hline$\Delta$ Trade (as a share of GDP) & $\begin{array}{c}-0.0608 * * * \\
{[2.84]}\end{array}$ & $\begin{array}{c}-0.0091 * * \\
{[2.43]}\end{array}$ & $\begin{array}{c}-0.0029 \\
{[1.29]}\end{array}$ & $\begin{array}{c}-0.0096 \\
{[1.01]}\end{array}$ & $\begin{array}{c}-0.0061 \\
{[1.63]}\end{array}$ & $\begin{array}{l}0.0035 \\
{[1.30]}\end{array}$ & $\begin{array}{c}-0.0035 \\
{[0.86]}\end{array}$ & $\begin{array}{c}-0.0021^{* *} \\
{[2.02]}\end{array}$ & $\begin{array}{c}-0.0080^{* *} \\
{[2.54]}\end{array}$ & $\begin{array}{c}-0.0216^{* * *} \\
{[2.82]}\end{array}$ \\
\hline Prices public consumption $\mathrm{t}-1$ & $\begin{array}{c}-0.0175 \\
{[1.32]}\end{array}$ & $\begin{array}{l}0.0017 \\
{[0.74]}\end{array}$ & $\begin{array}{c}-0.0009 \\
{[0.65]}\end{array}$ & $\begin{array}{c}-0.0054 \\
{[0.93]}\end{array}$ & $\begin{array}{l}0.0003 \\
{[0.15]}\end{array}$ & $\begin{array}{c}0.0029 * \\
{[1.70]}\end{array}$ & $\begin{array}{c}-0.0029 \\
{[1.15]}\end{array}$ & $\begin{array}{c}0.0011^{*} \\
{[1.70]}\end{array}$ & $\begin{array}{c}-0.0030 \\
{[1.55]}\end{array}$ & $\begin{array}{l}0.0007 \\
{[0.15]}\end{array}$ \\
\hline$\Delta$ Prices public consumption & $\begin{array}{c}0.1365^{* *} \\
{[2.44]}\end{array}$ & $\begin{array}{c}0.0191 * * \\
{[1.99]}\end{array}$ & $\begin{array}{l}0.0078 \\
{[1.33]}\end{array}$ & $\begin{array}{l}0.0119 \\
{[0.48]}\end{array}$ & $\begin{array}{l}0.0115 \\
{[1.18]}\end{array}$ & $\begin{array}{l}0.0034 \\
{[0.48]}\end{array}$ & $\begin{array}{c}0.0180 * \\
{[1.70]}\end{array}$ & $\begin{array}{l}0.0029 \\
{[1.07]}\end{array}$ & $\begin{array}{c}0.0271 * * * \\
{[3.29]}\end{array}$ & $\begin{array}{c}0.0415^{* *} \\
{[2.05]}\end{array}$ \\
\hline Unemployment t-1 & $\begin{array}{c}-0.0184 \\
{[0.40]}\end{array}$ & $\begin{array}{l}0.013 \\
{[1.64]}\end{array}$ & $\begin{array}{c}0.0066 \\
{[1.36]}\end{array}$ & $\begin{array}{c}-0.0060 \\
{[0.30]}\end{array}$ & $\begin{array}{l}0.0023 \\
{[0.29]}\end{array}$ & $\begin{array}{c}-0.0062 \\
{[1.05]}\end{array}$ & $\begin{array}{c}-0.0191 * * \\
{[2.10]}\end{array}$ & $\begin{array}{c}-0.0031 \\
{[1.34]}\end{array}$ & $\begin{array}{c}-0.0088 \\
{[1.26]}\end{array}$ & $\begin{array}{c}-0.0390^{* *} \\
{[2.25]}\end{array}$ \\
\hline$\Delta$ Unemployment & $\begin{array}{c}0.2867 * * \\
{[2.41]}\end{array}$ & $\begin{array}{l}0.0135 \\
{[0.69]}\end{array}$ & $\begin{array}{c}0.0247 * * \\
{[2.04]}\end{array}$ & $\begin{array}{c}0.1020^{* *} \\
{[2.02]}\end{array}$ & $\begin{array}{c}-0.0107 \\
{[0.55]}\end{array}$ & $\begin{array}{c}-0.0103 \\
{[0.73]}\end{array}$ & $\begin{array}{c}0.0081 \\
{[0.38]}\end{array}$ & $\begin{array}{l}0.0015 \\
{[0.27]}\end{array}$ & $\begin{array}{l}0.0224 \\
{[1.29]}\end{array}$ & $\begin{array}{r}0.0477 \\
{[1.11]}\end{array}$ \\
\hline Lagged dependent variable & $\begin{array}{c}-0.0049 \\
{[0.10]}\end{array}$ & $\begin{array}{c}-0.0963^{*} \\
{[1.90]}\end{array}$ & $\begin{array}{c}0.0913^{*} \\
{[1.71]}\end{array}$ & $\begin{array}{c}-0.0934^{*} \\
{[1.79]}\end{array}$ & $\begin{array}{c}-0.0267 \\
{[0.52]}\end{array}$ & $\begin{array}{c}0.1307 * * * \\
{[2.77]}\end{array}$ & $\begin{array}{l}0.0254 \\
{[0.49]}\end{array}$ & $\begin{array}{c}-0.0246 \\
{[0.48]}\end{array}$ & $\begin{array}{l}0.0591 \\
{[1.15]}\end{array}$ & $\begin{array}{c}0.1549 * * * \\
{[3.00]}\end{array}$ \\
\hline $\begin{array}{l}\text { Fixed country effects } \\
\text { Fixed period effects }\end{array}$ & $\begin{array}{l}\text { Yes } \\
\text { Yes }\end{array}$ & $\begin{array}{l}\text { Yes } \\
\text { Yes }\end{array}$ & $\begin{array}{l}\text { Yes } \\
\text { Yes }\end{array}$ & $\begin{array}{l}\text { Yes } \\
\text { Yes }\end{array}$ & $\begin{array}{l}\text { Yes } \\
\text { Yes }\end{array}$ & $\begin{array}{l}\text { Yes } \\
\text { Yes }\end{array}$ & $\begin{array}{l}\text { Yes } \\
\text { Yes }\end{array}$ & $\begin{array}{l}\text { Yes } \\
\text { Yes }\end{array}$ & $\begin{array}{l}\text { Yes } \\
\text { Yes }\end{array}$ & $\begin{array}{l}\text { Yes } \\
\text { Yes }\end{array}$ \\
\hline $\begin{array}{l}\text { Observations } \\
\text { Number of countries }\end{array}$ & $\begin{array}{c}552 \\
23\end{array}$ & $\begin{array}{c}552 \\
23\end{array}$ & $\begin{array}{c}552 \\
23\end{array}$ & $\begin{array}{c}552 \\
23\end{array}$ & $\begin{array}{c}552 \\
23\end{array}$ & $\begin{array}{c}552 \\
23\end{array}$ & $\begin{array}{c}552 \\
23\end{array}$ & $\begin{array}{c}552 \\
23\end{array}$ & $\begin{array}{c}552 \\
23\end{array}$ & $\begin{array}{c}552 \\
23\end{array}$ \\
\hline
\end{tabular}

Notes: Absolute value of $\mathrm{t}$ statistics in brackets; $*$ significant at $10 \% ; * *$ significant at $5 \%$; *** significant at $1 \%$ 
Table 4: Regression Results. 1990-2006. Error Correction Model.

Dynamic bias corrected estimator. Dependent variable: First differences of the expenditure categories (measured as a share of GDP).

\begin{tabular}{|c|c|c|c|c|c|c|c|c|c|c|}
\hline & $\begin{array}{c}(1) \\
\text { Public sector } \\
\text { size } \\
\end{array}$ & $\begin{array}{c}\text { (2) } \\
\text { Public services }\end{array}$ & $\begin{array}{c}\text { (3) } \\
\text { Defense }\end{array}$ & $\begin{array}{c}(4) \\
\text { Economic } \\
\text { services } \\
\end{array}$ & $\begin{array}{c}(5) \\
\text { Environmental } \\
\text { protection }\end{array}$ & $\begin{array}{c}(6) \\
\text { Housing }\end{array}$ & $\begin{array}{c}(7) \\
\text { Health }\end{array}$ & $\begin{array}{c}\text { (8) } \\
\text { Cultural affairs }\end{array}$ & $\begin{array}{c}\text { (9) } \\
\text { Education }\end{array}$ & $\begin{array}{c}\text { (10) } \\
\text { Social welfare }\end{array}$ \\
\hline \multirow[t]{2}{*}{ Ideology (leftwing) t-1 } & 0.0462 & -0.0575 & 0.0069 & 0.0424 & -0.0059 & -0.0021 & 0.0219 & 0.0070 & $0.0517 * * *$ & 0.0084 \\
\hline & {$[0.33]$} & {$[0.83]$} & {$[0.47]$} & {$[0.52]$} & {$[0.72]$} & {$[0.16]$} & {$[0.76]$} & {$[0.72]$} & [2.77] & {$[0.17]$} \\
\hline \multirow[t]{2}{*}{$\Delta$ Ideology (leftwing) } & -0.1646 & -0.0623 & -0.0154 & 0.085 & -0.0073 & 0.0003 & -0.0467 & 0.0023 & -0.0043 & -0.0944 \\
\hline & [0.89] & {$[0.68]$} & {$[0.82]$} & {$[0.79]$} & {$[0.68]$} & {$[0.02]$} & {$[1.27]$} & {$[0.19]$} & {$[0.17]$} & {$[1.45]$} \\
\hline \multirow[t]{2}{*}{ Total population t-1 } & $2 \times 10^{-8}$ & $7 \times 10^{-9}$ & $2 \times 10^{-8 * * * *}$ & $1 \times 10^{-9}$ & $-1 \times 10^{-9}$ & $-1 \times 10^{-9}$ & $-2 \times 10^{-9}$ & $-4 \times 10^{-10}$ & $3 \times 10^{-9}$ & $4 \times 10^{-9}$ \\
\hline & {$[0.54]$} & {$[0.38]$} & [4.00] & {$[0.06]$} & {$[0.60]$} & {$[0.29]$} & {$[0.19]$} & {$[0.14]$} & {$[0.67]$} & {$[0.25]$} \\
\hline \multirow[t]{2}{*}{$\Delta$ Total population } & $-1 \times 10^{-6}$ & $-3 \times 10^{-7}$ & $4 \times 10^{-8}$ & $-4 \times 10^{-7}$ & $3 \times 10^{-8}$ & $1 \times 10^{-7}$ & $-3 \times 10^{-8}$ & $8 \times 10^{-9}$ & $3 \times 10^{-8}$ & $-5 \times 10^{-7}$ \\
\hline & {$[1.32]$} & {$[0.52]$} & {$[0.37]$} & {$[0.64]$} & {$[0.51]$} & {$[1.00]$} & {$[0.13]$} & {$[0.10]$} & {$[0.22]$} & {$[1.21]$} \\
\hline \multirow[t]{2}{*}{ Young share t-1 } & 0.0518 & 0.0097 & -0.0194 & 0.1520 & $-0.0231^{*}$ & -0.0326 & -0.0366 & -0.009 & 0.0024 & 0.0433 \\
\hline & {$[0.23]$} & {$[0.09]$} & {$[0.82]$} & {$[1.19]$} & [1.76] & [1.63] & {$[0.79]$} & {$[0.58]$} & {$[0.08]$} & {$[0.54]$} \\
\hline \multirow[t]{2}{*}{$\Delta$ Young share } & -0.5873 & 0.3537 & -0.0532 & -0.459 & $-0.1638 *$ & $-0.3773 * * *$ & 0.0808 & -0.0545 & 0.0799 & -0.1298 \\
\hline & {$[0.38]$} & {$[0.47]$} & {$[0.33]$} & {$[0.52]$} & [1.81] & [2.68] & {$[0.26]$} & {$[0.52]$} & {$[0.39]$} & {$[0.24]$} \\
\hline \multirow[t]{2}{*}{ Elderly share t-1 } & -0.0232 & 0.0463 & $-0.0318 * * *$ & 0.0326 & 0.0033 & 0.0016 & -0.0103 & -0.0007 & 0.0091 & -0.0126 \\
\hline & {$[0.22]$} & {$[0.88]$} & [2.82] & {$[0.53]$} & {$[0.54]$} & {$[0.16]$} & {$[0.48]$} & {$[0.09]$} & {$[0.65]$} & {$[0.34]$} \\
\hline \multirow[t]{2}{*}{$\Delta$ Elderly share } & 0.0125 & 0.0352 & $-0.0177 * *$ & 0.0648 & 0.0026 & 0.0007 & -0.0127 & -0.0009 & 0.0015 & -0.0347 \\
\hline & {$[0.16]$} & {$[0.90]$} & [2.19] & {$[1.42]$} & {$[0.56]$} & {$[0.10]$} & {$[0.81]$} & {$[0.18]$} & {$[0.14]$} & {$[1.25]$} \\
\hline \multirow[t]{2}{*}{ Per capita income t-1 } & $-0.0002 *$ & $-3 \times 10^{-5}$ & $-8 \times 10^{-6}$ & -0.0001 & $-9 \times 10^{-6}$ & $-1 \times 10^{-5}$ & $-3 \times 10^{-6}$ & $-2 \times 10^{-6}$ & $-2 \times 10^{-6}$ & -0.0001 \\
\hline & [1.67] & [0.49] & {$[0.58]$} & {$[0.85]$} & [1.17] & {$[0.98]$} & [0.11] & {$[0.23]$} & {$[0.10]$} & [1.19] \\
\hline \multirow[t]{2}{*}{$\Delta$ Per capita income } & $-0.0016^{* * *}$ & $-0.0004 * *$ & $-0.0001 * *$ & -0.0002 & $-4 \times 10^{-5} *$ & $-3 \times 10^{-5}$ & $-0.0003 * * *$ & $-0.0001 * * *$ & $-0.0001 * *$ & $-0.0005 * * *$ \\
\hline & [4.52] & [2.09] & [2.53] & {$[0.90]$} & [1.92] & {$[0.91]$} & [3.77] & {$[2.60]$} & {$[2.56]$} & {$[3.75]$} \\
\hline \multirow[t]{2}{*}{ Trade (as a share of GDP) $t-1$} & $0.0362 * *$ & 0.0097 & 0.0009 & 0.011 & 0.0002 & 0.0009 & 0.0027 & -0.0002 & 0.0009 & $0.0102 *$ \\
\hline & [2.14] & {$[1.15]$} & {$[0.48]$} & {$[1.13]$} & {$[0.24]$} & {$[0.56]$} & {$[0.78]$} & {$[0.15]$} & {$[0.38]$} & [1.69] \\
\hline \multirow[t]{2}{*}{$\Delta$ Trade (as a share of GDP) } & 0.0327 & 0.0196 & 0.0043 & 0.0057 & -0.0004 & 0.0006 & -0.0009 & -0.0019 & 0.0002 & 0.0047 \\
\hline & {$[1.30]$} & {$[1.56]$} & {$[1.64]$} & {$[0.38]$} & {$[0.28]$} & {$[0.25]$} & {$[0.17]$} & {$[1.11]$} & {$[0.05]$} & {$[0.52]$} \\
\hline \multirow[t]{2}{*}{ Prices public consumption $\mathrm{t}-1$} & 0.0531 & 0.0106 & -0.0021 & 0.0061 & -0.0009 & 0.003 & 0.0046 & -0.0008 & 0.0026 & 0.015 \\
\hline & [1.63] & {$[0.66]$} & {$[0.60]$} & {$[0.32]$} & {$[0.48]$} & [0.98] & {$[0.70]$} & {$[0.37]$} & {$[0.60]$} & {$[1.27]$} \\
\hline \multirow[t]{2}{*}{$\Delta$ Prices public consumption } & $0.2103 * *$ & 0.0549 & 0.0113 & 0.0842 & $0.0218 * * *$ & $0.0237 * *$ & -0.0038 & 0.0049 & $0.0232 *$ & 0.0049 \\
\hline & [2.13] & {$[1.11]$} & {$[1.14]$} & {$[1.47]$} & {$[3.75]$} & {$[2.52]$} & {$[0.19]$} & {$[0.74]$} & {$[1.77]$} & {$[0.14]$} \\
\hline \multirow[t]{2}{*}{ Unemployment t-1 } & $-0.2845 * * *$ & -0.0768 & 0.0074 & -0.0962 & 0.0065 & -0.004 & -0.0109 & 0.0012 & 0.0002 & $-0.1166^{* * *}$ \\
\hline & {$[2.80]$} & {$[1.52]$} & {$[0.67]$} & {$[1.64]$} & {$[1.10]$} & {$[0.42]$} & {$[0.52]$} & {$[0.17]$} & {$[0.02]$} & [3.18] \\
\hline \multirow[t]{2}{*}{$\Delta$ Unemployment } & 0.061 & -0.0561 & 0.0188 & -0.0112 & -0.0025 & 0.0014 & $-0.0800 * *$ & -0.0153 & 0.0159 & 0.0769 \\
\hline & [0.34] & {$[0.62]$} & {$[1.02]$} & {$[0.11]$} & {$[0.24]$} & {$[0.08]$} & [2.21] & {$[1.23]$} & {$[0.67]$} & [1.24] \\
\hline \multirow[t]{2}{*}{ Lagged dependent variable } & $-0.1440 * *$ & $-0.2257 * * *$ & 0.0335 & $-0.4316^{* * *}$ & -0.0498 & -0.002 & 0.1123 & -0.0457 & -0.0727 & $0.1743 * * *$ \\
\hline & {$[2.27]$} & {$[3.64]$} & {$[0.47]$} & {$[7.24]$} & {$[0.81]$} & {$[0.07]$} & {$[1.64]$} & {$[0.70]$} & {$[1.07]$} & [2.61] \\
\hline Fixed country effects & Yes & Yes & Yes & Yes & Yes & Yes & Yes & Yes & Yes & Yes \\
\hline Fixed period effects & Yes & Yes & Yes & Yes & Yes & Yes & Yes & Yes & Yes & Yes \\
\hline Observations & 245 & 245 & 245 & 245 & 245 & 245 & 245 & 245 & 245 & 245 \\
\hline Number of countries & 20 & 20 & 20 & 20 & 20 & 20 & 20 & 20 & 20 & 20 \\
\hline
\end{tabular}

Notes: Absolute value of $t$ statistics in brackets; * significant at $10 \% ; * *$ significant at $5 \% ; * * *$ significant at $1 \%$ 


\section{Data description and sources}

Table A1. Descriptive Statistics. 1970-1997.

\begin{tabular}{|c|c|c|c|c|c|c|}
\hline Variable & Observations & Mean & Std. Dev. & Min & Max & Source \\
\hline Public sector size & 644 & 43.51 & 10.03 & 19.84 & 69.75 & $\begin{array}{l}\text { Sanz and Velázquez } \\
(2007)\end{array}$ \\
\hline Public services & 644 & 3.93 & 1.17 & 1.06 & 7.43 & $\begin{array}{l}\text { Sanz and Velázquez } \\
(2007)\end{array}$ \\
\hline Defense & 644 & 2.28 & 1.31 & 0.00 & 8.18 & $\begin{array}{l}\text { Sanz and Velázquez } \\
(2007)\end{array}$ \\
\hline Economic Affairs & 644 & 6.14 & 2.33 & 2.29 & 15.01 & $\begin{array}{l}\text { Sanz and Velázquez } \\
\text { (2007) }\end{array}$ \\
\hline $\begin{array}{l}\text { Transport and } \\
\text { Communications }\end{array}$ & 644 & 2.80 & 1.17 & 0.75 & 7.41 & $\begin{array}{l}\text { Sanz and Velázquez } \\
(2007)\end{array}$ \\
\hline Housing & 644 & 1.44 & 0.94 & 0.00 & 4.82 & $\begin{array}{l}\text { Sanz and Velázquez } \\
(2007)\end{array}$ \\
\hline Health & 644 & 5.26 & 1.49 & 1.47 & 12.61 & $\begin{array}{l}\text { Sanz and Velázquez } \\
(2007))\end{array}$ \\
\hline Cultural affairs & 644 & 0.87 & 0.50 & 0.00 & 2.71 & $\begin{array}{l}\text { Sanz and Velázquez } \\
\text { (2007) }\end{array}$ \\
\hline Education & 644 & 5.26 & 1.34 & 0.90 & 8.60 & $\begin{array}{l}\text { Sanz and Velázquez } \\
(2007)\end{array}$ \\
\hline Social welfare & 644 & 13.64 & 6.14 & 2.61 & 31.78 & $\begin{array}{l}\text { Sanz and Velázquez } \\
(2007)\end{array}$ \\
\hline Ideology (leftwing) & 626 & 2.86 & 0.88 & 1 & 4 & Potrafke (2009a) \\
\hline Total population & 644 & 32811.30 & 52085.99 & 205.00 & 272647.00 & OECD Health Data (2007) \\
\hline Young share & 644 & 21.88 & 3.81 & 14.68 & 32.34 & Worldbank (2007) \\
\hline Elderly share & 644 & 12.78 & 2.30 & 7.07 & 17.98 & Worldbank (2007) \\
\hline Share aged 15-64 & 629 & 52.97 & 6.03 & 42.50 & 73.50 & Worldbank (2007) \\
\hline Per capita income & 643 & 17676.67 & 6749.71 & 4281.56 & 38409.29 & Worldbank (2007) \\
\hline Trade (as a share of GDP) & 642 & 64.10 & 36.61 & 11.25 & 224.50 & Worldbank (2007) \\
\hline Prices public consumption & 623 & 50.62 & 28.83 & 0.17 & 102.84 & OECD (2008) \\
\hline Unemployment rate & 625 & 6.02 & 4.34 & 0.00 & 23.90 & OECD Health Data (2007) \\
\hline KOF index of globalization & 644 & 65.05 & 12.71 & 33.98 & 89.76 & $\begin{array}{l}\text { Dreher (2006) and Dreher } \\
\text { et al (2008b) }\end{array}$ \\
\hline Ideology (rightwing) & 625 & 0.30 & 0.36 & -0.57 & 1 & Bjørnskov (2008b) \\
\hline
\end{tabular}


Table A2. Descriptive Statistics. 1990-2006.

\begin{tabular}{|c|c|c|c|c|c|c|}
\hline Variable & Observations & Mean & Std. Dev. & Min & Max & Source \\
\hline Public sector size & 289 & 46.62 & 7.01 & 31.47 & 65.09 & OECD (2008) \\
\hline Public services & 289 & 9.15 & 2.68 & 3.61 & 17.61 & OECD (2008) \\
\hline Defense & 289 & 1.67 & 0.99 & 0.00 & 5.64 & OECD (2008) \\
\hline Economic Affairs & 289 & 4.72 & 1.22 & 2.19 & 11.10 & OECD (2008) \\
\hline Environmental protection & 289 & 0.65 & 0.35 & 0.00 & 1.82 & OECD (2008) \\
\hline Housing & 289 & 0.86 & 0.48 & 0.15 & 6.26 & OECD (2008) \\
\hline Health & 289 & 6.23 & 1.03 & 3.37 & 8.89 & OECD (2008) \\
\hline Cultural affairs & 289 & 1.08 & 0.59 & 0.15 & 3.66 & OECD (2008) \\
\hline Education & 289 & 5.72 & 1.40 & 2.34 & 9.55 & OECD (2008) \\
\hline Social welfare & 289 & 16.53 & 5.07 & 6.60 & 28.36 & OECD (2008) \\
\hline Ideology (leftwing) & 340 & 2.93 & 0.89 & 2 & 4 & Potrafke (2009a) \\
\hline Total population & 340 & $4.06 \mathrm{E}+07$ & $6.30 \mathrm{E}+07$ & 254800 & $2.99 \mathrm{E}+08$ & OECD (2008) \\
\hline Young share & 340 & 18.31 & 2.55 & 13.78 & 27.33 & Worldbank (2008) \\
\hline Elderly share & 340 & 14.99 & 2.46 & 10.64 & 39.65 & Worldbank (2008) \\
\hline Share aged $15-64$ & 340 & 66.77 & 1.51 & 61.32 & 69.77 & Worldbank (2008) \\
\hline Per capita income & 340 & 24045.15 & 8550.82 & 8479.00 & 54633.30 & Worldbank (2008) \\
\hline Trade (as a share of GDP) & 336 & 78.91 & 50.72 & 16.11 & 326.60 & Worldbank (2008) \\
\hline Prices public consumption & 339 & 93.08 & 17.42 & 34.77 & 144.59 & OECD:Economic Outlook \\
\hline Unemployment rate & 335 & 7.11 & 3.37 & 1.63 & 19.53 & OECD (2008) \\
\hline KOF index of globalization & 320 & 78.45 & 9.96 & 49.66 & 93.65 & $\begin{array}{l}\text { Dreher (2006) and Dreher et } \\
\text { al }(2008 b)\end{array}$ \\
\hline Ideology (rightwing) & 300 & 0.24 & 0.33 & -0.52 & 1 & Bjørnskov (2008b) \\
\hline
\end{tabular}


Table A3. Variables description

\begin{tabular}{|c|c|c|}
\hline Variable & Description & Source \\
\hline $\begin{array}{l}\text { Public sector size } \\
\text { (total spending) } \\
\text { Public Services } \\
\text { (sum of General public } \\
\text { services and Public } \\
\text { order and safety) }\end{array}$ & $\begin{array}{l}\text { Aggregate government spending excluding interests } \\
\text { as a share of GDP } \\
\text { 1. Executive and legislative organs, financial and fiscal } \\
\text { affairs, external affairs } \\
\text { 2. Foreign economic aid } \\
\text { 3. General services } \\
\text { 4. Basic research } \\
\text { 5. R\&D General public services } \\
\text { 6. General public services n.e.c. } \\
\text { 7. Public debt transactions } \\
\text { 8. Transfers of a general character between different levels } \\
\text { 9. Pof government } \\
\text { 10. Fire-protection services } \\
\text { 11. Law courts } \\
\text { 12. Prisons } \\
\text { 13. R\&D Public order and safety } \\
\text { 14. Public order and safety n.e.c. } \\
\text { as a share of GDP }\end{array}$ & OECD (2008) \\
\hline Defense & $\begin{array}{l}\text { 1. Military defense } \\
\text { 2. Civil defense } \\
\text { 3. Foreign military aid } \\
\text { 4. R\&D Defense } \\
\text { 5. Defense n.e.c. } \\
\text { as a share of GDP }\end{array}$ & OECD (2008) \\
\hline Economic affairs & $\begin{array}{l}\text { 1. General economic, commercial and labor affairs } \\
\text { 2. Agriculture, forestry, fishing and hunting } \\
\text { 3. Fuel and energy } \\
\text { 4. Mining, manufacturing and construction } \\
\text { 5. Transport } \\
\text { 6. Communication } \\
\text { 7. Other industries } \\
\text { 8. R\&D Economic affairs } \\
\text { 9. Economic affairs n.e.c. } \\
\text { as a share of GDP }\end{array}$ & OECD (2008) \\
\hline $\begin{array}{l}\text { Environmental } \\
\text { protection }\end{array}$ & $\begin{array}{l}\text { 1. Waste management } \\
\text { 2. Waste water management } \\
\text { 3. Pollution abatement } \\
\text { 4. Protection of biodiversity and landscape } \\
\text { 5. R\&D Environmental protection } \\
\text { 6. Environmental protection n.e.c. } \\
\text { as a share of GDP }\end{array}$ & OECD (2008) \\
\hline Housing & $\begin{array}{l}\text { 1. Housing development } \\
\text { 2. Community development } \\
\text { 3. Water supply } \\
\text { 4. } \text { Street lighting } \\
\text { 5. R\&D Housing and community affairs } \\
\text { 6. Environmental protection n.e.c. } \\
\text { as a share of GDP }\end{array}$ & OECD (2008) \\
\hline Health & $\begin{array}{l}\text { 1. Medical products, appliances and equipment } \\
\text { 2. Outpatient services } \\
\text { 3. Hospital services } \\
\text { 4. Public health services } \\
\text { 5. R\&D health } \\
\text { 6. Health n.e.c. } \\
\text { as a share of GDP }\end{array}$ & OECD (2008) \\
\hline
\end{tabular}


Variables description (continued).

\begin{tabular}{|c|c|c|}
\hline Variable & Description & Source \\
\hline Cultural affairs & $\begin{array}{ll}\text { 1. } & \text { Recreational and sporting services } \\
\text { 2. } & \text { Cultural services } \\
\text { 3. } & \text { Broadcasting and publishing services } \\
\text { 4. } & \text { Religious and other community services } \\
\text { 5. } & \text { R\&D Recreation, culture and religion } \\
\text { 6. } & \text { Recreation, culture and religion n.e.c. } \\
\text { as a share of GDP }\end{array}$ & OECD (2008) \\
\hline Education & $\begin{array}{l}\text { 1. Pre-primary and primary education } \\
\text { 2. Secondary education } \\
\text { 3. Post-secondary non-tertiary education } \\
\text { 4. Tertiary education } \\
\text { 5. Education not definable by level } \\
\text { 6. Subsidiary services to education } \\
\text { 7. R\&D Education } \\
\text { 8. Education n.e.c. } \\
\text { as a share of GDP }\end{array}$ & OECD (2008) \\
\hline Social welfare & $\begin{array}{ll}\text { 1. } & \text { Sickness and disability } \\
\text { 2. } & \text { Old age } \\
\text { 3. } & \text { Survivors } \\
\text { 4. } & \text { Family and children } \\
\text { 5. } & \text { Unemployment } \\
6 . & \text { Housing } \\
\text { 7. } & \text { Social exclusion n.e.c. } \\
\text { 8. } & \text { R\&D Social protection } \\
\text { 9. } & \text { Social protection n.e.c. } \\
\text { as a share of GDP }\end{array}$ & OECD (2008) \\
\hline Population & Resident population in thousands & Worldbank (2007) \\
\hline Young share & Population aged 14 and below as a share of total population & Worldbank (2007) \\
\hline Elderly share & Population aged 65 and above as a share of total population & Worldbank (2007) \\
\hline $\begin{array}{l}\text { Gross domestic } \\
\text { product (per capita) }\end{array}$ & $\begin{array}{l}\text { GDP per capita is gross domestic product divided by midyear } \\
\text { population. GDP at purchaser's prices is the sum of gross value } \\
\text { added by all resident producers in the economy plus any product } \\
\text { taxes and minus any subsidies not included in the value of the } \\
\text { products. It is calculated without making deductions for } \\
\text { depreciation of fabricated assets or for depletion and degradation } \\
\text { of natural resources. Data are in constant US dollars. }\end{array}$ & Worldbank (2007) \\
\hline Trade & $\begin{array}{l}\text { Imports of goods and services represent the value of all goods } \\
\text { and other market services received from the rest of the world. } \\
\text { They include the value of merchandise, freight, insurance, } \\
\text { transport, travel, royalties, license fees, and other services, such } \\
\text { as communication, construction, financial, information, business, } \\
\text { personal, and government services. They exclude labor and } \\
\text { property income (formerly called factor services) as well as } \\
\text { transfer payments. Data are in constant local currency. } \\
\text { Exports of goods and services represent the value of all goods } \\
\text { and other market services provided to the rest of the world. They } \\
\text { include the value of merchandise, freight, insurance, transport, } \\
\text { travel, royalties, license fees, and other services, such as } \\
\text { communication, construction, financial, information, business, } \\
\text { personal, and government services. They exclude labor and } \\
\text { property income (formerly called factor services) as well as } \\
\text { transfer payments. Data are in constant local currency. }\end{array}$ & Worldbank (2007) \\
\hline $\begin{array}{l}\text { Prices public } \\
\text { consumption }\end{array}$ & Deflator, Public consumption, $2000=100$ & $\begin{array}{l}\text { OECD: Economic } \\
\text { Outlook (2007) }\end{array}$ \\
\hline Unemployment Rate & Total unemployment, \% of labor force & $\begin{array}{l}\text { OECD Health } \\
\text { Data Base (2007) }\end{array}$ \\
\hline Share aged $15-64$ & Population aged between 15 and 64 as a share of total population & Worldbank (2007) \\
\hline
\end{tabular}


Variables description (continued).

\begin{tabular}{l|l|l}
\hline Variable & Description & Source \\
\hline KOF Index of & $\begin{array}{l}\text { The KOF Index of Globalization was introduced in 2002 (see } \\
\text { Dreher, 2006). The overall index covers the economic, social and } \\
\text { political dimensions of globalization. It defines globalization to } \\
\text { be the process of creating networks of connections among actors } \\
\text { at multi-continental distances, mediated through a variety of } \\
\text { flows including people, information and ideas, capital and goods. } \\
\text { Globalization is conceptualized as a process that erodes national } \\
\text { boundaries, integrates national economies, cultures, technologies } \\
\text { and governance and produces complex relations of mutual } \\
\text { interdependence. } \\
\text { More specifically, the three dimensions of the KOF index are } \\
\text { defined as: } \\
\begin{array}{l}\text { economic globalization, characterized as long distance flows of } \\
\text { goods, capital and services as well as information and } \\
\text { perceptions that accompany market exchanges; }\end{array}\end{array}$ & $\begin{array}{l}\text { political globalization, characterized by a diffusion of } \\
\text { government policies; and } \\
\text { social globalization, expressed as the spread of ideas, } \\
\text { information, images and people. }\end{array}$ \\
\hline
\end{tabular}

